

\title{
In situ investigations and reactive transport modelling of cement paste / argillite interactions in a saturated context and outside an excavated disturbed zone
}

Daniele Bartier, Isabelle Techer, Alexandre Dauzères, Philippe Boulvais, Marie-Madeleine Blanc-Valleron, Justo Cabrera

\section{To cite this version:}

Daniele Bartier, Isabelle Techer, Alexandre Dauzères, Philippe Boulvais, Marie-Madeleine BlancValleron, et al.. In situ investigations and reactive transport modelling of cement paste / argillite interactions in a saturated context and outside an excavated disturbed zone. Applied Geochemistry, 2013, 31, pp.94-108. 10.1016/j.apgeochem.2012.12.009 . insu-00818761

\section{HAL Id: insu-00818761 \\ https://hal-insu.archives-ouvertes.fr/insu-00818761}

Submitted on 12 Jul 2017

HAL is a multi-disciplinary open access archive for the deposit and dissemination of scientific research documents, whether they are published or not. The documents may come from teaching and research institutions in France or abroad, or from public or private research centers.
L'archive ouverte pluridisciplinaire HAL, est destinée au dépôt et à la diffusion de documents scientifiques de niveau recherche, publiés ou non, émanant des établissements d'enseignement et de recherche français ou étrangers, des laboratoires publics ou privés.

\section{(1) (1) $\$$}

Distributed under a Creative Commons Attribution - NonCommercial - NoDerivatives| 4.0 


\section{In situ investigations and reactive transport modelling of cement paste/ disturbed zone}

Danièle Bartier $^{\mathrm{a}}$, Isabelle Techer $^{\mathrm{b}, *}$, Alexandre Dauzères ${ }^{c}$, Philippe Boulvais ${ }^{\mathrm{d}}$, Marie-Madeleine Blanc-Valleron ${ }^{\mathrm{e}}$, Justo Cabrera ${ }^{\mathrm{c}}$

a CNRS UMR 7566, Université de Lorraine, BP 70239, 54506 Vandœuvre-lès-Nancy, France

${ }^{b}$ CNRS UMR 7330, Université de Nìmes, 30000 Nìmes, France

'IRSN, BP 17, 92262 Fontenay-aux-Roses, France

${ }^{d}$ CNRS-UMR 6118, Université de Rennes 1, CNRS, Campus de Beaulieu, Bat 15, 35042 Rennes Cedex, France

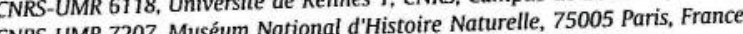

\section{A R T I L E 1 N F O}

\section{Introduction}

In France, the concepts of geological disposal facilities for high and intermediate-level long-lived radioactive wastes involve the use of argillaceous and cementitious materials. Owing to their composition, hardened cement paste and concrete will generate lo hyper-alkaline plumes (with $\mathrm{pH}$ values that can reach $12-13$. Berse plumes on the surround-

\footnotetext{
* Corresponding author. Tel: +33(0)4667099 73; fax: +33 (0)466709989. E-mail address: Isabelle.techer@unimes.fr (I. Techer).
}

\begin{abstract}
A B S T R A C T
The interactions between cementitious materials and a clayey deep formation were investigated by (the Tournemire Underground Research Laboratory (URL) of the 列 HYTEC code. The study forms part of the safety assessment framework for the deep geological disposal of high to intermediate level long-lived radioactive waste. The in situ context investigated in the Tournemire URL corresponds to an engineered cemented borehole crosscutting the Toarcian argillite formation. The argillite/CEM II cement paste contacts have been in place over $18 \mathrm{a}$ and were sampled in a saturated context outside the excavated disturbed zone (EDZ). Studies of the mineralogy (XRD, carbonatometry, SEM and TEM), petrophysical properties (BET) and geochemistry (TOC, Sr contents, C, O and Sr isotopes, EDS analyses) were carried out both on the argillite and on the cement paste in contact. Alteration of the cement paste is clearly expressed by decalcification and the opermation of C-S-H phases was identified re mainly due to the dissoluton of pillite interface, along with secondary carbonates at the outer most contact. Geochemical measurements argue for the introduction of a sedimentary fluid into the 列 列 hypothesis is considere argillite/cement paste contact at a very early stage. After this stage, the transport ithe cement paste to the argillite. The changes brought 列 $11-13 \mathrm{~mm}$ in a so-called 'black rim', in which carabout by these fluids are observed over a thicknified in the matrix of the sediment. An illitization process (the inner part. Geochemical analyses show that the argillite disturbances are strictly confined to the black rim. Theoretin mood



ing medium and, in particular, the argillaceous barriers, must be evaluated and understood in any safety assessment analysis. Given the importance of the issue, numerous studies have been undertaken on the interactions between argillaceous and cementitious materials. For instance, laboratory experiments have focused on this topic (e.g. Eberl et al., 1993; Bauer and Berger, 1998; Adler et al. 1999: Read et al. 2001; Ramirez et al., 2002; Cuevas et al., 2006; Devol-Brown et al., 2007; Dauzères et al., 2010). The results have supplied input data for predictive modelling (e.g. Savage et al., 2002; De Windt et al., 2004, 2008; Pfingsten et al., 2006; Trotignon et al., 2007; Fernández et al., 2010). Natural systems 
have also been investigated that are appropriate for the understanding of alkaline fluid propagation in a clayey medium, even though there are few published results (see Savage, 2011). The most well known analogue sites are located in Jordan, at Maqarin and Khushaym Matruk (Khoury et al., 1985; Alexander et al., 1992; Steefel and Lichtner, 1998; Smellie et al., 2001; Baker et al., 2002; Techer et al., 2006; Elie et al., 2007; Fourcade et al., 2007). Different studies over the last few years have focused on what are known as "engineered analogues" [termed "industrial analogues" by Savage (2011)], which correspond to cementitious material emplaced artificially in contact with an argillaceous formation. As an example, the Tournemire experimental platform (IRSN, Aveyron) is of great interest, since it makes use of engineered analogues with various cementing materials in contact with an argillite formation at depth. A 15-a-old engineered analogue consisting of a concreted borehole - the DM borehole was initially studied by Tinseau et al. (2006), who gave a description of the mineralogical modifications induced in the argillite at a concrete contact. This study was backed up by modelling and discussed by De Windt et al. (2008). Gaboreau et al. (2011) and Techer et al. (2012) also applied petro-physical and geochemical approaches to characterize the DM borehole to investigate the origin and extent of the modifications, as well as their imprint on the confinement properties of the argillite. All the samples studied in the DM borehole were collected in a saturated zone, close to an excavated tunnel and thus in the excavated disturbed zone (EDZ) of this tunnel. The discontinuities in this EDZ have been clearly identified as preferential pathways for the propagation of alkaline fluids in the argillaceous formation (De Windt et al., 2008; Techer et al. 2012). Nevertheless, in a deep storage facility, saturation of the clayey formation is expected in the final stages of operations at the depth of the storage cell, or during the post-closure period, mainly in the environment around cementitious cells used for Intermediate Long Lived Waste. During these stages, the imprint of the EDZ could be less pronounced due to self-sealing. To obtain better constraints on these conditions, a second engineered analogue is being investigated in the Tournemire experimental station. This analogue is provided by the CD-borehole, which contains a hardened cement paste that has remained for $18 \mathrm{a}$ in contact with the argillite formation in a saturated zone far from the EDZ. The present study provides a post-mortem characterization of both the cementitious and argillaceous materials of the CD-borehole, combined with reactive transport modelling using the HYTEC code. Two main topics are discussed: (i) the evolution of the hardened cement paste over $18 \mathrm{a}$ in the saturated zone, (ii) the propagation and imprint of an alkaline plume on the saturated argillite in the absence of structural discontinuities. The duration of contact, the constant saturation conditions and the absence of influence from a mechanically disturbed zone, give rise to a singular type of contact that has never been reported before in the literature.

\section{Engineered analogues at the Tournemire experimental station}

The experimental station of Tournemire has been described in many studies (Boisson et al., 2001; Tinseau et al., 2006; Matray et al., 2007; Gaboreau et al., 2011; Techer et al., 2012). It consists of a disused tunnel (excavated between 1882 and 1888) and recent lateral galleries (excavated between 1996 and 2008) located at depth in a 200-m thick Toarcian formation. Many studies and experiments have been carried out at the station by the Institute for Radioprotection and Nuclear Safety (IRSN), some involving the emplacement of cement pastes or concretes in contact with the argillite. These engineered analogues of argillaceous/cementitious contacts have evolved over various time durations, ranging from a few to nearly 20 years, and under various conditions. In this way, a relatively large panel of interactions can be observed and modelled in order to achieve a better assessment of a potential nuclear waste storage. In 1991, the CD vertical borehole was drilled down into the tunnel substrate to carry out hydro-geological measurements. After the experiments, the borehole was filled with a hardened cement paste described in more detail below.

\section{Methods}

\subsection{Sampling}

In 2009, the CD borehole was over-cored in the uppermost $10 \mathrm{~m}$ with an internal coring diameter of $20 \mathrm{~cm}$ (Fig. 1). For technical reasons, the coring was carried out with water drawn from the channel located under the tunnel foundation raft. To avoid potenchannel located under the tunnel foundation raft the argillite crown was not included in the sampling. After drilling, the CD-core was described, left to dried and conditioned in Al bags on site. Four sections were selected for analyses, at depths of $3.18 \mathrm{~m}, 7.00 \mathrm{~m}$, $8.54 \mathrm{~m}$ and $9.94 \mathrm{~m}$, respectively, which are labelled as CD318, CD700, CD854 and CD994. The CD318 section is located in the lower part of the Tournemire tunnel EDZ, whereas the three other sections (CD700, CD854 and CD994) are clearly outside the EDZ (Fig 1). Macroscopic observations highlight the occurrence of a black rim about $10 \mathrm{~mm}$ thick in the argillite at the cement paste interface. The thickness of this rim varies slightly with depth of sampling. The argillite and cement paste were sampled at increasing distance from the interface in the four studied CD core sections. A precise micro-saw (Brot $\odot$ Technologies) was used to collect a thin rim of material by cutting 1 -mm-thick sections at increasing distance from the interface, allowing the acquisition of sampling profiles in both the argillite and the cement paste.

\subsection{Analytical methods}

Microscopic observations and analyses were carried out with a scanning electron microscope (SEM, HITACHI S3500N, IRSN Fontenay aux Roses) coupled with a Brücker ${ }^{(8)}$ EDS-SDD system for the semi-quantitative chemical analyses, as well as with a transmission electron microscope (TEM, Philips CM20, SCMEM Nancy). Quantitative measurements of carbonate contents were carried out on a Mélières manocalcimeter (MCM, MNHN Paris) on $50 \mathrm{mg}$ of powder. The isotopic compositions of $C\left(\delta^{13} \mathrm{C}\right)$ and $\mathrm{O}\left(\delta^{18} \mathrm{O}\right)$ of carbonates were determined on a gas source mass spectrometer with a triple collector (VG SIRA 10, Geosciences Rennes) after reaction of around $30 \mathrm{mg}$ of whole rock powder with $100 \%$ orthophosphoric acid at $50^{\circ} \mathrm{C}$ (McCrea, 1950). Long-term standards survey (NBS 19 and in-lab Prolabo Rennes) allows estimating the analytical precision at $0.1 \%$ for both $\mathrm{C}$ and $\mathrm{O}$ isotope systems. The soluble phases extracted from the argillite and the cement paste were characterized by analysing their $\mathrm{Sr}$ contents and $\mathrm{Sr}$ isotope compositions $\left({ }^{87} \mathrm{Sr} /{ }^{86} \mathrm{Sr}\right)$. This extraction was carried out by acid acetic dissolution of $30 \mathrm{mg}$ of powder using a high acid/rock ratio to prevent saturation. The reaction was maintained until the end of $\mathrm{CO}_{2}$ degassing. The leachates were used for $\mathrm{Sr}$ separation (Pin et al., 2003) and isotopic measurements. Measurements were performed by thermal ionization solid source mass spectrometry (Finnigan Triton TI, GIS Nîmes) with an analytical error $(2 \sigma)$ of about $5 \times 10^{-6}$. The external reproducibility of the isotopic measurements was checked by repetitive analysis of the NBS987 standard, yielding a mean value of $0.710258 \pm 2 \times 10^{-6}(2 \sigma)$. X-ray diffraction patterns were obtained on whole-rocks and on the $<2 \mu \mathrm{m}$ fraction using a Siemens D501 instrument (MNHN, Paris). Analytical procedures are described in detail in Tinseau et al. (2006). Semi-quantitative proportions were estimated using the EVAC 


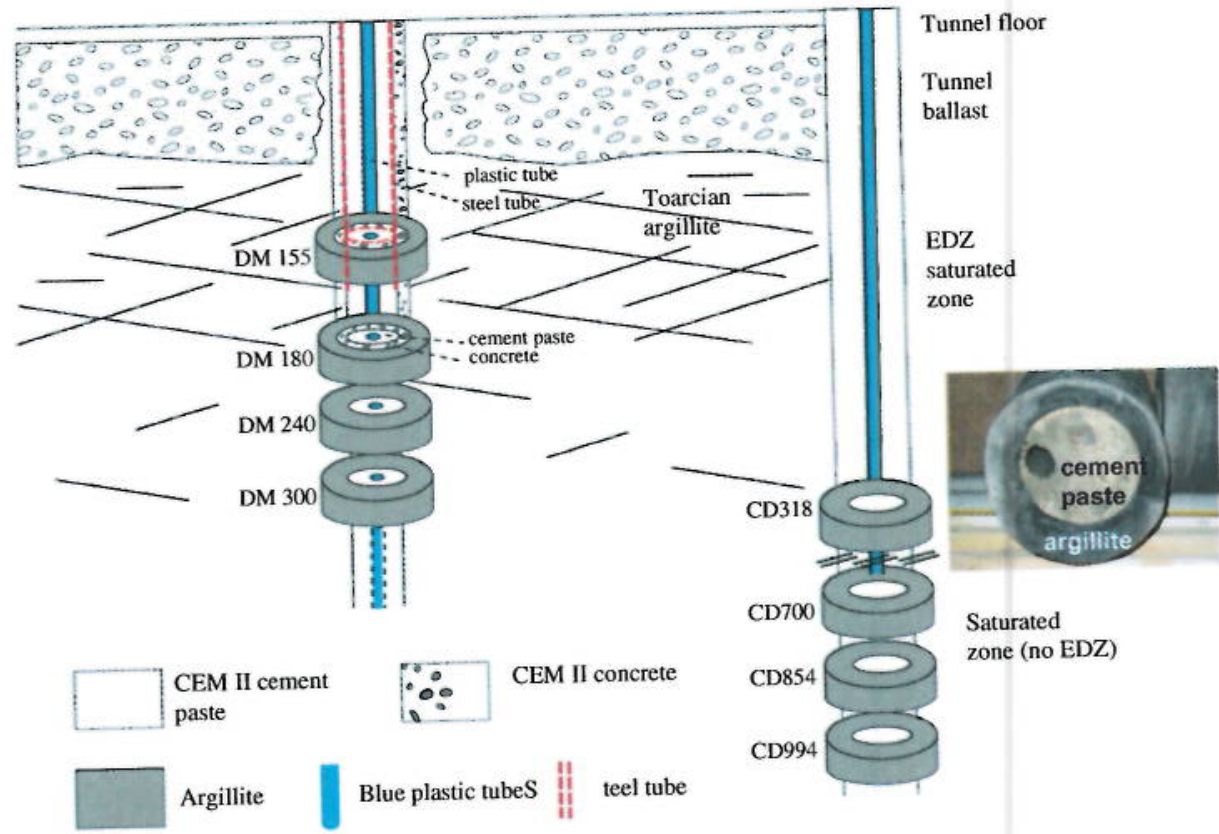
Fig. 1. Scheme of the $\mathrm{CD}$ borehole implantation in the Tournemire Experimental Platform and comparison cont between the cement paste on the inside and the studied samples: CD318 in EDZ, CD700, CD854 and CD994 outside EDZ. Image of a CD core sample section showick rim of black coloured argillite (black rim) is observed the Toarcian argillite (rim of around $40-75 \mathrm{~cm}$ in thickness systematically at the interface between the two materials.

software, and the PDF2 database of the ICDD. The calcite content estimated by comparing the X-ray diffraction patterns and the MCM analysis was introduced as an internal standard. Analyses of total organic $\mathrm{C}$ (TOC) were performed with an ELEMENTAR Vario Pyro Cube (IRSN, Fontenay aux Roses). Three repeat measurements were carried out systematically on each sample. The specific surface-area of the argillaceous and cementing materials was measured by the BET method using a COULTER SA3100 instrument equipped with version 2.13 of the COULTER software (IRSN, Fontenay aux Roses).

\subsection{Modelling strategy}

\subsubsection{Reactive transport modelling}

Two codes were used in this study to model the $\mathrm{CD}$ engineered analogue: (i) the HYTEC code (Van der Lee et al., 2003), which is specifically designed to model reactive transport in saturated and unsaturated environments. This code takes into account variations in geochemistry and physical parameters due to mineralogical changes in the solids; (ii) the CHESS code, which takes into account geochemical speciation (Van der Lee, 1998) and simulates the chemical reactions in a given system. Although it carries out calculations at thermodynamic equilibrium, kinetic parameters can also be taken into account. In the present case, all the calculations were performed assuming thermodynamic equilibrium using the Newton-Raphson iterative method. All phases of the system are conton-Raphson iterative minerals, solutions, aqueous and gaseous species. The transport is simulated with the module R2D2, which is coded in finite elements, to carry out the calculations in $1 \mathrm{D}$ and $2 \mathrm{D}$ in diffusive and/or convective transport. The transport module is coupled to the chemistry module with the following equation:

$\frac{\partial \omega C_{i}^{\text {sol }}}{\partial t}=\operatorname{div}\left(D^{*} \overrightarrow{\mathrm{grad}} \cdot C_{i}^{\text {sol }}-C_{i}^{\text {sol } U}\right)-\frac{\partial \omega C_{i}^{p}}{\partial t}$

where $\omega$ is the porosity, $C_{i}^{\text {sol }}$ the mobile concentration of chemical component $i$ in a fluid phase, $C_{i}^{p}$ the immobile concentration of $i$ (precipitation), $D^{*}$ the diffusion tensor and $U$ is the Darcy velocity (convection coefficient).

The transport in the argillaceous material is considered as being totally controlled by diffusion so that the reactive transport equation can be simplified as follows:

$\frac{\partial \omega C_{i}^{\text {sol }}}{\partial t}=\operatorname{div}\left(D^{*} \overrightarrow{\operatorname{grad}} \cdot C_{i}^{\text {sol }}\right)-\frac{\partial \omega C_{i}^{p}}{\partial t}$

The transport of fluid containing high concentrations of aqueous species can induce several reactions with the solid phase. These chemical transformations (dissolution and/or precipitation) induce porosity changes that lead to an evolution of the material according to the diffusion coefficient. In HYTEC, the effective diffusion coefficient is then related to the porosity evolution according to Archie's law (3) (Lagneau, 2003):

$D_{e}(\omega)=D_{e}\left(\omega_{0}\right) \cdot\left(\frac{\omega-\omega_{p}}{\omega_{0}-\omega_{p}}\right)^{m}$

where $\omega_{0}$ is the initial porosity, $\omega$ the calculated porosity, $\omega_{p}$ the diffusive percolation threshold and $m$ is the Archie coefficient (or cementation factor). The value of the Archie coefficient depends on the material and on the environment, and ranges between 1.3 and 3.5 (fit parameter). In the present case, an Archie coefficient value of 3 was used for the clayey and cementitious materials (Trotignon et al., 2007).

\subsubsection{The database}

The present study makes use of the "cemdata07" thermodynamic database (Lothenbach et al., 2008). This database (Table 1) describes all the minerals likely to be present in the cementitious materials at $25^{\circ} \mathrm{C}$ and supposed to form during alteration. The equilibrium constants are recalculated using the basic set of species from CHESS. All mineral species in the argillite that are likely to be formed in the clay/concrete interactions are added to the database (source: chess.tdb). However, with regard to the experimental results (this study and that of Tinseau et al., 2006) that 
Table 1

Thermodynamic database used in the numerical simulations.

\begin{tabular}{|c|c|c|}
\hline Phase & Structural formula & $\log \mathrm{Kf}\left(25^{\circ} \mathrm{C}\right)$ \\
\hline Calcite & $\mathrm{Ca}^{2+}+\mathrm{HCO}_{3}^{-} \rightarrow \mathrm{CaCO}_{3}(\mathrm{~s})+\mathrm{H}^{+}$ & -1.85 \\
\hline Anhydrite & $\begin{array}{l}\mathrm{Ca}^{2+}+\mathrm{HCO}_{3}^{-} \rightarrow \mathrm{CaCO}_{3}(\mathrm{~s})+\mathrm{H}^{+} \\
\mathrm{Ca}^{2+}+\mathrm{SO}_{4}^{2-} \rightarrow \mathrm{CaSO}_{4}(\mathrm{~s})\end{array}$ & 4.36 \\
\hline Gypsum & $\begin{array}{l}\mathrm{Ca}^{2+}+\mathrm{SO}_{4}^{2-} \rightarrow \mathrm{CaSO}_{4}(\mathrm{~s}) \\
\mathrm{Ca}^{2+}+\mathrm{SO}_{4}^{2-} \rightarrow \mathrm{CaSO}_{4}, 2 \mathrm{H}_{2} \mathrm{O}(\mathrm{s})\end{array}$ & 4.58 \\
\hline Portlandite & $\begin{array}{l}\mathrm{Ca}^{2+}+\mathrm{SO}_{4}^{2-} \rightarrow \mathrm{CaSO}_{4}, 2 \mathrm{H}_{2} \mathrm{O}(\mathrm{s}) \\
\mathrm{Ca}^{2+}+2 \mathrm{H}_{2} \mathrm{O} \rightarrow \mathrm{Ca}(\mathrm{OH})_{2}+2 \mathrm{H}^{+}\end{array}$ & -22.8 \\
\hline C-S-H 1.65 & $\begin{array}{l}\mathrm{Ca}^{2+}+2 \mathrm{H}_{2} \mathrm{O} \rightarrow \mathrm{Ca}(\mathrm{OH})_{2}+2 \mathrm{H}^{+} \\
1.65 \mathrm{Ca}^{2+}+\mathrm{SiO}_{2}(\mathrm{aq})+3.3 \mathrm{H}_{2} \mathrm{O} \rightarrow 1.65 \mathrm{CaO} \cdot \mathrm{SiO}_{2} \cdot 1.65\left(\mathrm{H}_{2} \mathrm{O}\right)+3.3 \mathrm{H}^{+}\end{array}$ & -28.56 \\
\hline C-S-H 1.5 & $1.5 \mathrm{Ca}^{2+}+\mathrm{SiO}_{2}(\mathrm{aq})+3 \mathrm{H}_{2} \mathrm{O} \rightarrow 1.5 \mathrm{CaO} \cdot \mathrm{SiO}_{2} \cdot 1.5\left(\mathrm{H}_{2} \mathrm{O}\right)+3 \mathrm{H}^{+}$ & -25.15 \\
\hline C-S-H 1.4 & $\begin{array}{l}1.5 \mathrm{Ca}^{2+}+\mathrm{SiO}_{2}(\mathrm{aq})+3 \mathrm{H}_{2} \mathrm{O} \rightarrow 1.5 \mathrm{CaO} \cdot \mathrm{SiO}_{2} \cdot 1.5\left(\mathrm{H}_{2} \mathrm{O}\right)+3 \mathrm{H} \\
1.4 \mathrm{Ca}^{2+}+\mathrm{SiO}_{2}(\mathrm{aq})+2.8 \mathrm{H}_{2} \mathrm{O} \rightarrow 1.4 \mathrm{CaO} \cdot \mathrm{SiO}_{2} \cdot 1.4\left(\mathrm{H}_{2} \mathrm{O}\right)+2.8 \mathrm{H}^{+}\end{array}$ & -22.91 \\
\hline C-S-H 1.3 & $\begin{array}{l}1.4 \mathrm{Ca}^{2+}+\mathrm{SiO}_{2}(\mathrm{aq})+2.8 \mathrm{H}_{2} \mathrm{O} \rightarrow 1.4 \mathrm{CaO} \cdot \mathrm{SiO}_{2} \cdot 1.4\left(\mathrm{H}_{2} \mathrm{O}\right)+2.0 \mathrm{H} \\
1.3 \mathrm{Ca}^{2+}+\mathrm{SiO}_{2}(\mathrm{aq})+2.6 \mathrm{H}_{2} \mathrm{O} \rightarrow 1.3 \mathrm{CaO} \cdot \mathrm{SiO}_{2} \cdot 1.3\left(\mathrm{H}_{2} \mathrm{O}\right)+2.6 \mathrm{H}^{+}\end{array}$ & -20.71 \\
\hline C-S-H 1.2 & $\begin{array}{l}1.3 \mathrm{Ca}^{2+}+\mathrm{SiO}_{2}(\mathrm{aq})+2.6 \mathrm{H}_{2} \mathrm{O} \rightarrow 1.3 \mathrm{CaO} \cdot \mathrm{SiO}_{2} \cdot 1.3\left(\mathrm{H}_{2} \mathrm{O}\right)+2.0 . \\
1.2 \mathrm{Ca}^{2+}+\mathrm{SiO}_{2}(\mathrm{aq})+2.4 \mathrm{H}_{2} \mathrm{O} \rightarrow 1.2 \mathrm{CaO} \cdot \mathrm{SiO}_{2} \cdot 1.2\left(\mathrm{H}_{2} \mathrm{O}\right)+2.4 \mathrm{H}^{+}\end{array}$ & -18.57 \\
\hline C-S-H 1.1 & $\begin{array}{l}1.2 \mathrm{Ca}^{2+}+\mathrm{SiO}_{2}(\mathrm{aq})+2.4 \mathrm{H}_{2} \mathrm{O} \rightarrow 1.2 \mathrm{CaO} \cdot \mathrm{SiO}_{2} \cdot 1.2\left(\mathrm{H}_{2} \mathrm{O}\right)+2.4 \mathrm{n} \\
1.1 \mathrm{Ca}^{2+}+\mathrm{SiO}_{2}(\mathrm{aq})+2.2 \mathrm{H}_{2} \mathrm{O} \rightarrow 1.1 \mathrm{CaO} \cdot \mathrm{SiO}_{2} \cdot 1.1\left(\mathrm{H}_{2} \mathrm{O}\right)+2.2 \mathrm{H}^{+}\end{array}$ & -16.4 \\
\hline C-S-H 1 & $\begin{array}{l}1.1 \mathrm{Ca}^{2+}+\mathrm{SiO}_{2}(\mathrm{aq})+2.2 \mathrm{H}_{2} \mathrm{O} \rightarrow 1 . \mathrm{CaO} \cdot \mathrm{SiO}_{2} \cdot 1 .\left(\mathrm{H}_{2} \mathrm{O}\right)+2.2 \mathrm{H} \\
\mathrm{Ca}^{2+}+\mathrm{SiO}_{2}(\mathrm{aq})+2 \mathrm{H}_{2} \mathrm{O} \rightarrow 1 \mathrm{CaO} \cdot \mathrm{SiO}_{2} \cdot\left(\mathrm{H}_{2} \mathrm{O}\right)+2 \mathrm{H}^{+}\end{array}$ & -14.3 \\
\hline C-S-H 0.8 & $\begin{array}{l}\mathrm{Ca}^{2+}+\mathrm{SiO}_{2}(\mathrm{aq})+2 \mathrm{H}_{2} \mathrm{O} \rightarrow 1 \mathrm{CaO} \cdot \mathrm{SiO}_{2} \cdot\left(\mathrm{H}_{2} \mathrm{O}\right)+2 \mathrm{H}^{2} \\
0.8 \mathrm{Ca}^{2+}+\mathrm{SiO}_{2}(\mathrm{aq})+1.6 \mathrm{H}_{2} \mathrm{O} \rightarrow 0.8 \mathrm{CaO} \cdot \mathrm{SiO}_{2} \cdot 0.8\left(\mathrm{H}_{2} \mathrm{O}\right)+1.6 \mathrm{H}^{+}\end{array}$ & -10.43 \\
\hline $\mathrm{SiO}_{2}$ amorphous & $\begin{array}{l}0.8 \mathrm{Ca}^{2+}+\mathrm{SiO}_{2}(\mathrm{aq})+1.6 \mathrm{H}_{2} \mathrm{O} \rightarrow 0.8 \mathrm{CaO} \cdot \mathrm{SiO}_{2} \cdot 0.8\left(\mathrm{H}_{2} \mathrm{O}\right)+1.0 \mathrm{H} \\
\mathrm{SiO}_{2}(\mathrm{aq}) \rightarrow \mathrm{SiO}_{2}(\mathrm{am})\end{array}$ & 2.71 \\
\hline Ettringite & $6 \mathrm{Ca}^{2+}+2 \mathrm{Al}^{3-}+3 \mathrm{SO}_{4}^{2-}+38 \mathrm{H}_{2} \mathrm{O} \rightarrow \mathrm{Ca}_{6} \mathrm{Al}_{2}\left(\mathrm{SO}_{4}\right)_{3}(\mathrm{OH})_{12} \cdot 26 \mathrm{H}_{2} \mathrm{O}+12 \mathrm{H}^{+}$ & -56.87 \\
\hline Tricarboaluminate & $3 \mathrm{HCO}_{3}^{-}+6 \mathrm{Ca}^{2+}+2 \mathrm{Al}^{3+}+38 \mathrm{H}_{2} \mathrm{O} \rightarrow \mathrm{Ca}_{6} \mathrm{Al}_{2}\left(\mathrm{CO}_{3}\right)_{3}(\mathrm{OH}) 12.26 \mathrm{H}_{2} \mathrm{O}+15 \mathrm{H}^{+}$ & -86.25 \\
\hline Thaumasite & $2 \mathrm{SiO}_{2}(\mathrm{aq})+2 \mathrm{SO}_{4}^{2-}+6 \mathrm{Ca}^{2+}+2 \mathrm{HCO}_{3}^{-}+32 \mathrm{H}_{2} \mathrm{O} \rightarrow \mathrm{Ca}_{6}\left(\mathrm{SiO}_{3}\right)_{2}\left(\mathrm{SO}_{4}\right)_{2}\left(\mathrm{CO}_{3}\right)_{2} \cdot 30 \mathrm{H}_{2} \mathrm{O}+6 \mathrm{H}^{+}$ & -18.88 \\
\hline Katoite silicated & $\begin{array}{l}2 \mathrm{SiO}_{2}(\mathrm{aq})+2 \mathrm{SO}_{4}^{-+}+6 \mathrm{Ca}^{2+}+2 \mathrm{HCO}_{3}+32 \mathrm{H}_{2} \mathrm{O} \rightarrow \mathrm{Cd}_{6}\left(10.4 \mathrm{H}_{2} \mathrm{O} \rightarrow 3 \mathrm{CaO} \cdot \mathrm{Al}_{2} \mathrm{O}_{3} \cdot 0.8 \mathrm{SiO}_{2} \cdot 4.4 \mathrm{H}_{2} \mathrm{O}+12 \mathrm{H}^{+}\right. \\
0.8 \mathrm{SiO}_{2}(\mathrm{aq})+3 \mathrm{Ca}^{2+}+2 \mathrm{Al}^{+}++\mathrm{H}^{+}\end{array}$ & -68.54 \\
\hline Monocarboaluminate & $\begin{array}{l}0.8 \mathrm{SiO}_{2}(\mathrm{aq})+3 \mathrm{Ca}^{2+}+2 \mathrm{Al}++10.4 \mathrm{H}_{2} \mathrm{O} \rightarrow \mathrm{Hal}^{2+} \mathrm{Ca}^{2+}+2 \mathrm{Al}^{3+}+\mathrm{HCO}_{3}^{-}+17 \mathrm{H}_{2} \mathrm{O} \rightarrow 4 \mathrm{CaO} \cdot \mathrm{Al}_{2} \mathrm{O}_{3} \cdot \mathrm{CO}_{2} \cdot 11 \mathrm{H}_{2} \mathrm{O}+13 \mathrm{H}^{+}\end{array}$ & -80.62 \\
\hline Hemicarboaluminate & $\begin{array}{l}4 \mathrm{Ca}^{2+}+2 \mathrm{Al}^{3+}+\mathrm{HCO}_{3}^{-}+17 \mathrm{H}_{2} \mathrm{O} \rightarrow 4 \mathrm{CaO} \cdot \mathrm{Al}_{2} \mathrm{O}_{3} \cdot \mathrm{CO}_{2} \cdot \mathrm{H}_{2} \mathrm{O}+13 \mathrm{H} \\
4 \mathrm{Ca}^{2+}+2 \mathrm{Al}^{3-}+0.5 \mathrm{HCO}_{3}^{-}+18.5 \mathrm{H}_{2} \mathrm{O} \rightarrow 4 \mathrm{CaO} \cdot \mathrm{Al}_{2} \mathrm{O}_{3} \cdot 0.5 \mathrm{CO}_{2} \cdot 12 \mathrm{H}_{2} \mathrm{O}+13.5 \mathrm{H}^{+}\end{array}$ & -91.8 \\
\hline Hydrotalcite &  & -99.56 \\
\hline Brucite & $\begin{array}{l}6 \mathrm{Mg}^{2+}+2 \mathrm{Al}^{3+}+16 \mathrm{H}_{2} \mathrm{O}+\mathrm{HCO}_{3}\left[-\mathrm{J} \rightarrow \mathrm{Mg}_{6} \cdot \mathrm{Al}_{2} \cdot \mathrm{CO}_{3} \cdot(\mathrm{OH}) 16+17 \mathrm{Mg}\right. \\
\mathrm{Mg}^{2+}+2 \mathrm{H}_{2} \mathrm{O} \rightarrow \mathrm{Mg}(\mathrm{OH})_{2}+2 \mathrm{H}^{+}\end{array}$ & -16.98 \\
\hline Kaolinite & $\begin{array}{l}\mathrm{Mg}^{2+}+2 \mathrm{H}_{2} \mathrm{O} \rightarrow \mathrm{Mg}(\mathrm{OH})_{2}+2 \mathrm{H}^{+} \\
2 \mathrm{Al}^{3+}+2 \mathrm{SiO}_{2}+5 \mathrm{H}_{2} \mathrm{O} \rightarrow \mathrm{Al}_{2} \mathrm{Si}_{2} \mathrm{O}_{5}(\mathrm{OH})_{4}+6 \mathrm{H}^{+}\end{array}$ & -7.2 \\
\hline Illite & $\begin{array}{l}2 \mathrm{Al}^{3+}+2 \mathrm{SiO}_{2}+5 \mathrm{H}_{2} \mathrm{O} \rightarrow \mathrm{Al}_{2} \mathrm{Si}_{2} \mathrm{O}_{5}(\mathrm{OH})_{4}+6 \mathrm{H}^{+} \\
0.25 \mathrm{Mg}^{2+}+0.6 \mathrm{~K}^{+}+2.3 \mathrm{Al}^{3+}+3.5 \mathrm{SiO}_{2}+5 \mathrm{H}_{2} \mathrm{O} \rightarrow \mathrm{K}_{0.6} \mathrm{Mg}_{0.25} \mathrm{Al}_{2.3} \mathrm{Si}_{3.5} \mathrm{O}_{10}(\mathrm{OH})_{2}+8 \mathrm{H}^{+}\end{array}$ & -9.03 \\
\hline Montmorillonite-Ca & 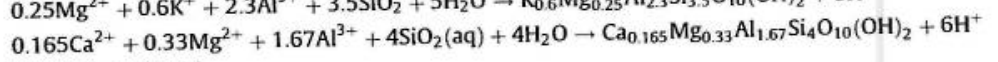 & -2.49 \\
\hline Quartz & 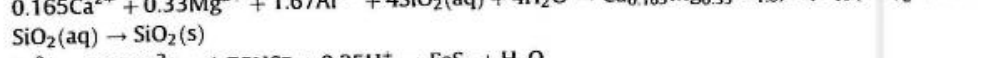 & 4 \\
\hline Pyrite & $\mathrm{Fe}^{2+}+0.25 \mathrm{SO}_{4}^{2-}+1.75 \mathrm{HS}^{-}+0.25 \mathrm{H}^{+} \rightarrow \mathrm{FeS}_{2}+\mathrm{H}_{2} \mathrm{O}$ & 24.65 \\
\hline
\end{tabular}

never displayed zeolites neoformation, all zeolite phases were removed from the database. In this framework, the C-S-H system of the "cemdata07" database was modified to include seven new C-S-H phases already used by Codina (2007) and validated by comparison with experimental data (Fig. 2). These new phases are described with the following ratios: $1.65,1.5,1.4,1.3,1.2$, $1.1,1$ and 0.8 . They supplement the database that initially considered only jennite and tobermorite as C-S-H. This discrete model
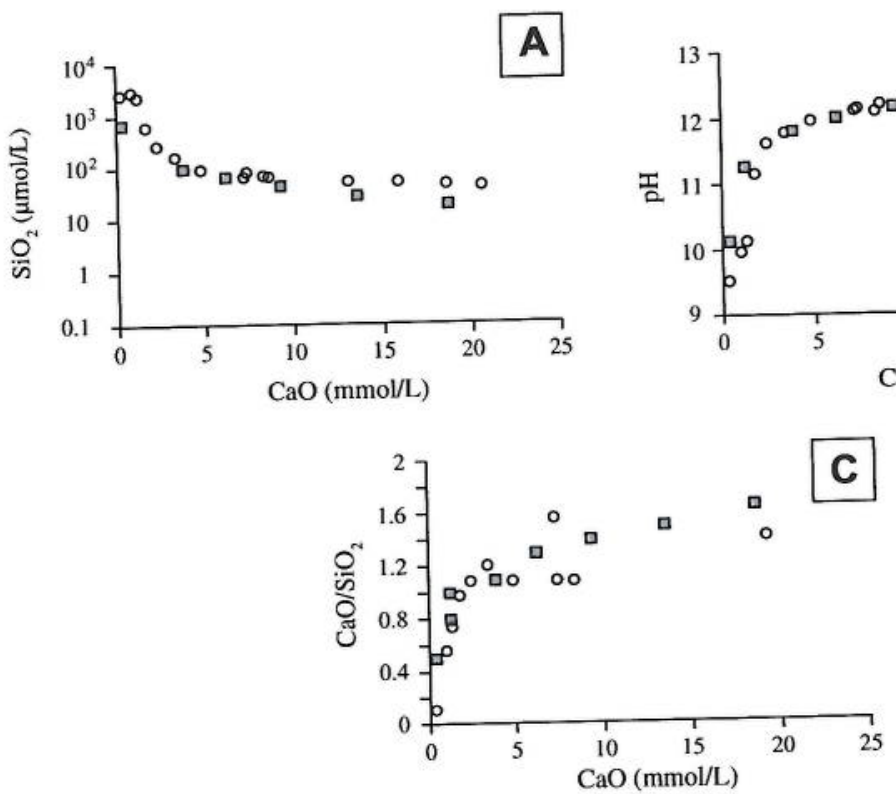

Chen, 2004。

Model C-S-H is also in agreement with the experimental data of Chen et al. (2004).

\subsubsection{Geometry and meshing}

The numerical simulations are based on a geometrical system defined with two successive rectangles of $10 \mathrm{~cm}$ in length and $4 \mathrm{~cm}$ in height (cement paste on left and argillite on right). Considering that the disturbed zone is very thin relative to the 
large thickness of cementitious and argillaceous materials, the left and right boundaries are considered as chemically constant and a 1D horizontal grid is imposed with a mesh size of $1 \mathrm{~mm}$.

\subsubsection{Data selection}

It was difficult to obtain the composition of the cement paste used in 1991 to fill the CD-borehole due to the absence of a quality control procedure in the $1990 \mathrm{~s}$. In an attempt to determine its composition, an EDS-SEM analysis was performed in the unaltered zone of the $C D$ hardened cement paste. The results were compared with chemical data for different cements provided by the LAFARGE@ Company, and a good agreement is obtained with the cement CEM II/A-LL 42,5N CE CP2 NF (84\% of clinker) from the Sète works, which was the cement production site that supplied the experimental station of Tournemire during the 1990s.

The mineralogical composition of the hardened cement paste (Table 2) is the result of a numerical simulation after total hydration of the clinker. Several assumptions are applied for the formation of hydrates during clinker hydration: (i) $\mathrm{C} 3 \mathrm{~S}$ and $\mathrm{C} 2 \mathrm{~S}$ are the source of portlandite and $\mathrm{C}-\mathrm{S}-\mathrm{H}$, (ii) gypsum reacts totally with $\mathrm{C} 3 \mathrm{~A}$ and partly with $\mathrm{C} 4 \mathrm{AF}$ to form ettringite, with $\mathrm{S}$ being the limiting reactant in the reaction, (iii) the remaining $\mathrm{Al}$ imposes formation of a carboaluminate phase, (iiii) the remaining carbonate content imposes the formation of calcite. The mineralogical system is considered to be invariant, with each mineralogical component controlling one chemical species: $\mathrm{C}-\mathrm{S}-\mathrm{H}$ controls $\mathrm{Si}$, portlandite controls $\mathrm{Ca}$, ettringite controls $\mathrm{S}$, hemicarboaluminate controls $\mathrm{Al}$ and calcite controls the carbonate. The water/cement ratio $(w / c)$ used in the 1990s is not known. An intermediate w/c ratio of 0.45 is imposed in the modelling. The mineralogical composition, its stability and the abundances of mineral phases are all defined at thermodynamic equilibrium with the CHESS code. A strong concentration of $\mathrm{KOH}$ is imposed in the pore solution to obtain a $\mathrm{pH}$ equal to 13.4, representative of the very high $\mathrm{pH}$ in this type of material. The mineralogical composition (Table 2 ), as well as the physical and transport properties of the Tournemire argillite, are extracted from De Windt et al. (2008). The mineralogical composition of the argillite is as follows: calcite, quartz, montmorillonite$\mathrm{Ca}$, illite, kaolinite and pyrite. The $\mathrm{CO}_{2}$ partial pressure is imposed in the argillite zone, using a value of $1 \times 10^{-2} \mathrm{~atm}$ as against $3.4 \times 10^{-4} \mathrm{~atm}$ in the atmosphere. All the calculations are simply carried out at thermodynamic equilibrium. Only quartz is controlled by a kinetic law of dissolution and precipitation. The kinetic formulation implemented in HYTEC is described by De Windt et al. (2008). The imposed kinetic parameter is equal to $1 \times 10^{-17} \mathrm{~mol} /$ $\mathrm{m}^{2} / \mathrm{s}$ (De Windt et al., 2008). As regards the pore solution (Table 2) controlled and generated by the modelled mineralogical composition, the $\mathrm{SO}_{4}^{2-}$ and $\mathrm{Cl}^{-}$concentrations are imposed to fit the post-mortem measurements. In the same way, the electrical charge balance is adjusted by the $\mathrm{Na}$ concentration.

\section{In situ investigations of cement paste and argillite in contact in the $\mathrm{CD}$-borehole}

\subsection{Mineralogical and petrophysical evolutions}

\subsubsection{In the cement paste}

In the $\mathrm{CD}$ borehole close to the contact with the argillite, the cement paste shows a macroscopically homogeneous alteration front with a thickness of about $1 \mathrm{~cm}$. The $\mathrm{Ca}$ and $\mathrm{C}$ mapping of this zone carried out by SEM-EDS microprobe suggests an opening of macroporosity linked to decalcification (Fig. $3 \mathrm{~A}$ ). In fact, an enrichment in $C$ is observed in the alteration zone ( 40 at.\% as against 15 at.\% in the unaltered zone); it seems moreover that carbonation is maximal in contact with the clayey rock. As the content of $\mathrm{C}$ is linked both to the embedding resin (polished section preparation) and the degree of carbonation of the cement material, it provides qualitative information about the macroporosity: close to the argillite, in the alteration front, the macroporosity is higher. In parallel with the $\mathrm{C}$ enrichment, the Ca concentration decreases (7-8\% atomic weight in the alteration front as against $15 \%$ in the unaltered zone). In the same way, the $\mathrm{CaO} / \mathrm{SiO}_{2}$ ratio decreases over the first $100 \mu \mathrm{m}$ of the alteration front (Fig. 3B). The XRD patterns (Fig. 3C) clearly show the total or partial dissolution of portlandite over a distance of 3-4 mm away from the rim in contact with the argillite. SEM observations corroborate these mineralogical tendencies, so the decrease in Ca content is well related to portlandite dissolution. The remaining $\mathrm{Ca}$ is associated with $\mathrm{C}-\mathrm{S}-\mathrm{H}$ and $\mathrm{Ca}$

Table 2

Data used for the numerical simulations.

\begin{tabular}{|c|c|c|c|}
\hline Hardened cement paste (DM and CD) & Hardened cement paste & & Argillite \\
\hline \multicolumn{4}{|c|}{ Mineralogical composition (mol/L of pore solution) } \\
\hline Portlandite & 19.1 & Calcite & 32.5 \\
\hline C-S-H 1.65 & 16.2 & Illite & 11.2 \\
\hline Hemicarboaluminate & 0.8 & Kaolinite & 0.38 \\
\hline \multirow[t]{2}{*}{ Calcite } & 1.3 & Montmorillonite-Ca & 7.9 \\
\hline & & Pyrite & 0.1 \\
\hline \multirow{2}{*}{$\begin{array}{l}\text { Porosity } \\
\text { De }\left(\mathrm{m}^{2} / \mathrm{s}\right)\end{array}$} & 0.3 & Porosity & 0.1 \\
\hline & $\begin{array}{l}\text { Pore solutions (mmol/L) } \\
\text { Modelling }\end{array}$ & Modelling & Measurements \\
\hline \multicolumn{4}{|c|}{ Kinetics rate for quartz (dissolution and precipitation): $1 \times \overline{10^{-17} \mathrm{~mol} / \mathrm{m}^{2} / \mathrm{s} \text { at } 25^{\circ} \mathrm{C}}$} \\
\hline $\mathrm{Na}$ & - & 23.5 & 23.5 \\
\hline K & 500 & 0.7 & 0.8 \\
\hline $\mathrm{Ca}$ & 0.9 & 1.9 & 1.5 \\
\hline $\mathrm{Si}$ & $5.1 \times 10^{-5}$ & 0.1 & 0.03 \\
\hline $\mathrm{Mg}$ & - & 0.1 & 0.7 \\
\hline $\mathrm{Cl}$ & & 4.5 & 4.5 \\
\hline $\mathrm{HCO}_{3}$ & - & 5.2 & 4.6 \\
\hline $\mathrm{pH}$ & 13.4 & 7.4 & 7.7 \\
\hline $\mathrm{pCO}_{2}(\mathrm{~atm})$ & - & $1 \times 10^{2}$ & $1 \times 10^{2}$ \\
\hline
\end{tabular}

In bold: imposed data in the modelling.

a Bensenouci (2010). 

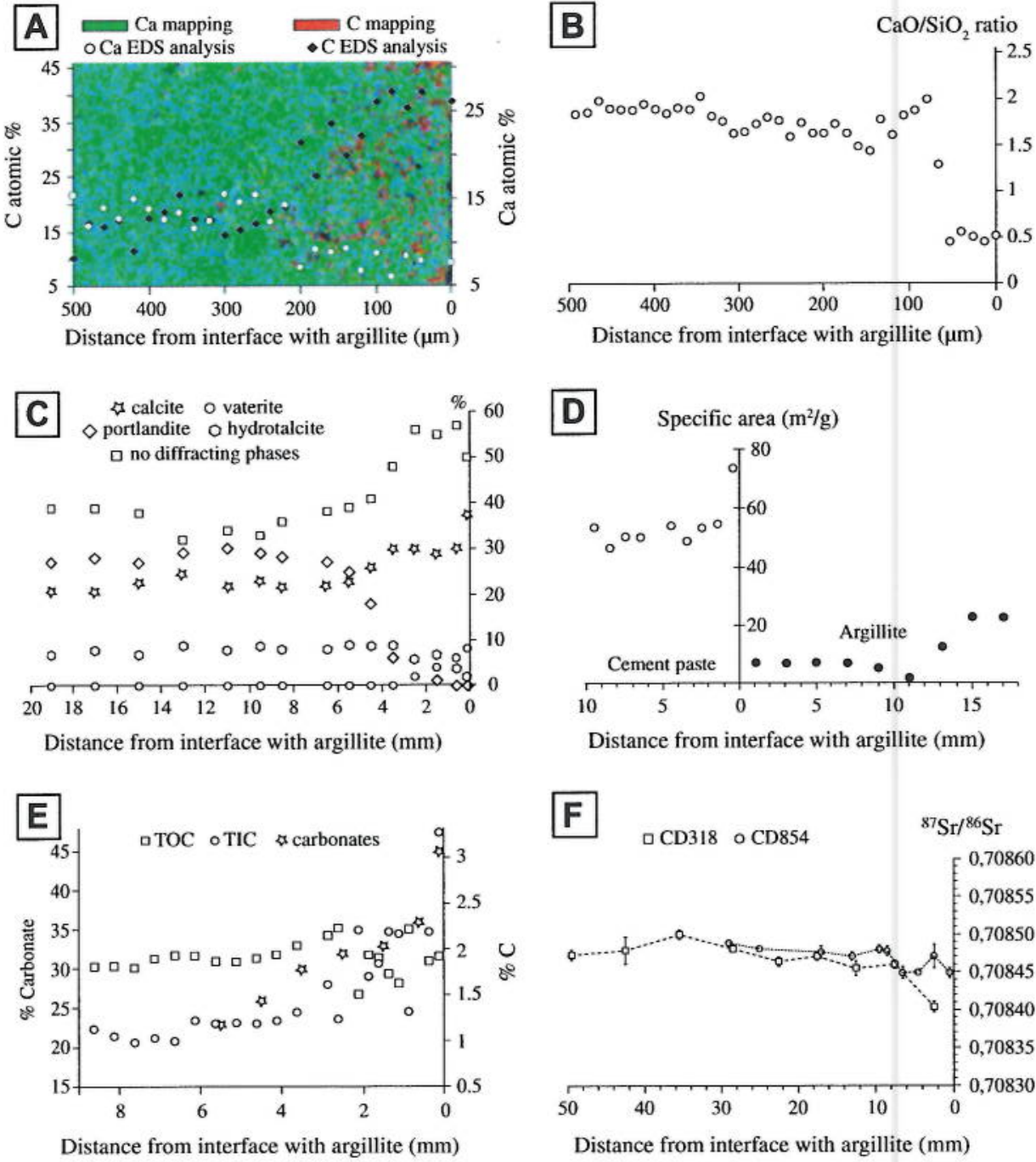

Fig. 3. Modifications of CEM II cement paste properties at the interface of the CD borehole. (A) Ca and C at.\% profiles parallel to SEM-EDX mapping scan with Ca in green and C in red; (B) $\mathrm{CaO} / \mathrm{SiO}_{2}$ ratio profile; (C) XRD mineralogical profiles; (D) specific area profile obtained by BET analyses; (E) TOC. TIC and \% carbonate; (F) evolution of Sr isotope composition $\left({ }^{87} \mathrm{Sr} /{ }^{86} \mathrm{Sr}\right.$ ratio) in samples $\mathrm{CD} 318$ and $\mathrm{CD} 854$.

carbonates. The portlandite dissolution is total within a distance of $500 \mu \mathrm{m}$ from the alteration front, linked to the intense decalcification near the interface. The outermost edge of the front shows the presence of Ca carbonates, mainly calcite but also vaterite in relatively high quantities ( $8 \%$ near the interface). Calcium silicate hydrates (C-S-H) reported as a non diffracting phase, have a relative abundance of about $40 \%$ in the unaltered zone and between $50 \%$ and $60 \%$ in the altered zone. The BET analyses allow determining the specific surface of samples from the alteration front (Fig. 3D), with values increasing in the cement paste, from $50 \mathrm{~m}^{2} / \mathrm{g}$ in the unaltered zone to $75 \mathrm{~m}^{2} / \mathrm{g}$ near the interface of the alteration front. This result is in good agreement with the XRD semi-quantitative analyses, highlighting an increase in C-S$\mathrm{H}$ abundance that can explain the increase in specific surface. Two kinds of analytical approach help to determine the content of carbonate phases in the studied samples. The MCM measurements define the quantity of carbonate in the samples, while the TOC-METRE analyses discriminate between organic and inorganic carbonate content. The results are compared in Fig. 3E. The MCM results clearly reflect the formation of carbonate in the cementitious material over a distance of $4 \mathrm{~mm}$, which is supported by the large increase of inorganic C content. By comparing these results with the XRD analyses discussed above, the affected thickness fits perfectly with the formation of calcite and vaterite.

\subsubsection{In the argillite}

Macroscopic observations of all the deep samples of the $C D$ overcore (CD700-CD994) reveal the presence of a black rim at the interface with the cement paste, resembling the structures previously described by Tinseau et al. (2006) and Techer et al. (2012). The thickness of this black rim varies slightly according to the sampling depth, being 12,13 and $11 \mathrm{~mm}$ for samples CD700, CD854 and CD994 (coming from the outside-EDZ), respectively. For sample CD318, the black rim is slightly thinner ( $10 \mathrm{~mm}$ thick) and comparable to that of the DM-engineered analogue, both type of samples being located in the tunnel EDZ (Tinseau et al., 2006; Gaboreau et al., 2011; Techer et al., 2012). It has been demonstrated that in this EDZ argillite alteration was not only restricted to the black rim, but also extended further, over a thickness twice that of the black rim. Changes were identified at two scales: (i) in the black rim, in which they were attributed to a propagation of a cementitious fluid through the argillite matrix, (ii) over this rim, 
where disturbances were linked to propagation along EDZ discontinuities.

Whole-rock XRD patterns obtained from various samples of the black rims display a mineralogical assemblage similar to that determined for a reference Toarcian sample, as published in Tinseau et al. (2006) and Techer et al. (2012). Samples are characterized by predominant phyllosilicates (illite, micas, kaolinite and chlorite), carbonates (calcite, dolomite), $\mathrm{K}$ and $\mathrm{Na}$-Ca feldspars and pyrite. The clay mineral assemblage (Fig. 4) determined after air-dried and ethylene glycol treatment is also similar for all samples, and is characterized by chlorite, non-expandable dioctahedral layers (illite or mica) and kaolinite. In all samples, decomposition of the patterns from the 'air-dried illite + illite/smectite mixed layer minerals (MLM) zone' requires the combination of five elementary peaks to obtain a good fit. These peaks are assigned to a well crystallized illite (WCI) or mica at $\sim 10 \AA$, a poorly crystallized illite (PCI at $\sim 10.1 \AA$ ), two MLMs with a high proportion of illite layers [MLM1 more than $90 \%(\sim 10.6 \AA)$ and MLM2 more than $75 \%(\sim 12.3 \AA)$ ] and a chlorite $(\sim 14.3 \AA)$. As observed with the air-dried treatment, decompositions of the 'glycolated illite + MLM zone' patterns reveal the predominance of PCI + MLM1 ( $\sim 10.9 \AA$ and $\sim 10 \AA)$ and MLM2 $(\sim 12.5 \AA$ and $\sim 9.4 \AA)$, as well as the occurrence of $\mathrm{WCI}$ and chlorite. The clay fractions of the $\mathrm{CD}$ samples collected "outside-EDZ" display very small variations compared to the published data for the 'within-EDZ' samples of the DM borehole and CD318. A slight increase in MLM is only observed far away from the contact, in the outer part of the black rim (between 10 and $12 \mathrm{~mm}$, Fig. 4A), which is correlated with a slight increase of the width of the peak at half height of the MLM1 and a slight decrease of the MLM/PCl ratio (Fig. 4B). The TEM observations can help to explain slight variations. First, the outermost edge of the black rim also displays a specific pattern with a very well developed newly-formed illite phase expressed as laths overgrowing mixed-layer illite/smectite (Fig. 5A). Unfortunately, the laths are so fine and small that count rates during EDS analysis are very low, and combined with the effects of beam damage, in particular ionization of K (Van Der Pluijm et al., 1998) the newly-formed illite composition remains uncertain. Outside the black rim, in undisturbed samples, the calculated structural formula of the MLM is comparable to the phase described in Charpentier et al. (2004) using the Harvey (1943) method based on 11 oxygen atoms per half unit-cell. The MLM particles of the black rim samples are poorer in Si than the MLM particles of the unaltered samples (3.3-3.4 versus 3.5-3.6). Most analyses of both samples indicate contents of $0.2 \mathrm{Fe}$ and $0.15 \mathrm{Mg}$. The $\mathrm{Al}$ content in octahedral sites is more significant in black rim samples than in undisturbed samples (1.6-1.7 versus $1.5-1.6)$. In both samples, the interlayer occupancy of MLM particles is dominated by $\mathrm{K}$ which ranges from 0.2 to 0.8 atoms with a mode at $0.3-0.4$ for unaltered samples and a mode at 0.5 for black rim samples. The Ca content is also more significant in black rim samples than in undisturbed samples (0-0.2 versus $0-0.09)$; the $\mathrm{Na}$ content is variable (from 0 to 0.06 ). In summary, MLM from black rim samples are enriched in $\mathrm{Al}$ and $\mathrm{K}$ and are poorer in Si. Such an evolution could likely involve illitization. Illitization of MLM is also evidenced by specific surface-area measurements. In fact, the values of specific surface-area in the black rim, ranging from about 7 to $2 \mathrm{~m}^{2} / \mathrm{g}$ at the extreme part of the black fringe (Fig. 3D), are clearly lower than those measured in the reference Toarcian argillite far from the interface, which yields a value of around $22 \mathrm{~m}^{2} / \mathrm{g}$. Such a drastic decrease of the specific surface-area, reflecting a reduction of the ion exchange capacity of the clayey rock, could be consistent with an illitization process. In this context, illitization could be considered as maximal at the actual interface between the black rim and the supposedly undisturbed clayey rock.
TEM observations also indicated the occurrence of $\mathrm{C}-\mathrm{S}-\mathrm{H}$ phases in the black rim. These phases exhibit mainly two types of morphology: fibrillar bundles (Fig. 5C) and a foil-like structure (Fig. 5D). Whatever their appearance, the $\mathrm{C}-\mathrm{S}-\mathrm{H}$ phases show a gel structure indicated by their diffuse halo XRD patterns as shown in Fig. 5. Although the sample preparations used for analysis represent only a negligible proportion of the collected samples, it would seem that the size and abundance of the $\mathrm{C}-\mathrm{S}-\mathrm{H}$ phases decrease in the black rim with increasing distance from the contact. TEM observations argue for a predominant foil-like morphology of $\mathrm{C}-\mathrm{S}-\mathrm{H}$ in the argillite matrix of the black rim. Based on TEM-EDS analysis, a Ca Al silicate hydrate mineral (C-A-S-H) could be used to describe a large number of these $\mathrm{Ca}$ silicate hydrates. Indeed, as in clay minerals, the $\mathrm{Al}$ of the $\mathrm{C}-\mathrm{S}-\mathrm{H}$ can be substituted either in the octahedral sites of $\mathrm{Ca}$, or in the tetrahedral sites of $\mathrm{Si}$ (Hidalgo et al., 2007). Nevertheless, TEMEDS analyses of C-(A)-S-H reveal minor traces of $\mathrm{K}$ in some cases, which could suggest a "mixture" containing tiny amounts of clay minerals (but insufficient to be discriminated in the diffraction halo). Another explanation could be that the $\mathrm{K}^{+}$measured in $\mathrm{C}-\mathrm{S}-\mathrm{H}$ is of cementitious origin, being released during the cement paste alteration. In fact, large amounts of $\mathrm{KOH}$ are expected to be release from this material during alteration. Diffusion of the $\mathrm{K}^{+}$ and $\mathrm{OH}^{-}$ions in the argillaceous matrix could occur along with the capture of $\mathrm{K}^{+}$in secondary $\mathrm{C}-\mathrm{S}-\mathrm{H}$ phases. To back up this hypothesis, $\mathrm{Si} / \mathrm{Ca}$ ratios are plotted versus $\mathrm{Al} / \mathrm{Ca}$ ratios (Fig. 6) measured in $\mathrm{C}-(\mathrm{A})-\mathrm{S}-\mathrm{H}$ displaying only amorphous-type diffraction patterns: $\mathrm{C}-(\mathrm{A})-\mathrm{S}-\mathrm{H}$ with traces of $\mathrm{K}$ cannot be truly discriminated from $\mathrm{C}-(\mathrm{A})-\mathrm{S}-\mathrm{H}$ phases without $\mathrm{K}$. Elemental ratios for $\mathrm{C}-\mathrm{S}-\mathrm{H}$ from the black rim are comparable with those obtained from cement pastes. For all samples, it appears that hydrates formed in the black rim of the argillite close to the cement paste are significantly enriched in $\mathrm{Si}$ (high $\mathrm{Si} / \mathrm{Ca}$ ratios) compared to $\mathrm{C}-(\mathrm{A})-\mathrm{S}-\mathrm{H}$ present in the cement pastes. The chemistry of $\mathrm{C}-(\mathrm{A})-\mathrm{S}-\mathrm{H}$ in the cement pastes is comparable to that reported in the literature (Richardson, 1999, 2000, 2008; Taylor et al., 2007). The higher $\mathrm{Si} / \mathrm{Ca}$ ratio of $\mathrm{C}-(\mathrm{A})-\mathrm{S}-\mathrm{H}$ in the black rim could not merely result from a tiny combination with clay minerals. The best explanation involves an effective decrease in Ca content and a substitution of $\mathrm{Al}$ in $\mathrm{C}-\mathrm{S}-\mathrm{H}$, together with, as mentioned above, the capture of $\mathrm{K}$ in the $\mathrm{C}-\mathrm{S}-\mathrm{H}$ structure.

A large variety of secondary minerals or mineral dissolution processes are described in the literature dealing with experimental cement/rock interactions. Similarities between these data and the present study can be highlighted by the occurrence of phases such as C-(A)-S-H and/or calcite (Adler et al., 1999; Claret et al., 2002; Ramirez et al., 2002; Dauzères et al., 2010; Fernández et al., 2010), and through the illitization of illite/smectite mixed-layer minerals or smectite (Eberl et al., 1993; Bauer and Berger, 1998; Adler et al., 1999; Claret et al., 2002; Ramirez et al., 2002; Mosser-Ruck and Cathelineau, 2004). However, a few discrepancies can be pointed out concerning (i) quartz and kaolinite dissolution and (ii) zeolite precipitation. Quartz dissolution was not identified in the CD-analogue, in contrast to the process proposed by Tinseau et al. (2006) for the DM-analogue. Kaolinite dissolution was not observed in the present study, whereas it was identified by Bauer and Berger (1998) and Claret et al. (2002). In these two latter studies, kaolinite dissolution was observed under "extreme conditions" of high alkaline water/rock ratios. These conditions do not correspond to those expected during the propagation of an alkaline plume in an argillite massif, such as assumed in the $\mathrm{CD}$ environment at Tournemire. While zeolite precipitation is sometimes observed during experimental investigations (Bauer and Berger, 1998; Adler et al., 1999; Vigil de la Villa et al., 2001; Ramirez et al., 2002; Bouchet et al, 2004; Cuevas et al., 2006), it is not currently highlighted in natural or engineered analogues studies (Tinseau et al., 2006; Yamaguchi 
D. Bartier et al./A



Fig. 4. XRD profiles of CD854 samples. (A) XRD clay fraction patterns of argillite samples in the black rim after air dried (AD) and ethylene glycol (G) treatment; (B) decomposition of the clay fraction in the area between $5^{\circ}$ and $11^{\circ} 2 \theta$.

et al., 2012), with the exception of the very old Maqarin (Jordan) natural analogue (Baker et al., 2002; Smellie, 1998; Smellie et al., 2001). In agreement with the results from Maqarin, zeolite formation is obtained in modelling mainly when considering long-term conditions (De Windt et al., 2004; Trotignon et al., 2006, 2007; Marty et al., 2009; Fernández et al., 2010).

Other changes in the black rim involve the carbonate contents and geochemical properties. Considering MCM data, a significant increase of the carbonate content is observed in the black rim of all the $\mathrm{CD}$ sections, which contain about $1 \mathrm{wt} . \%$ more carbonates than the reference Toarcian argillite (Table 3 ) and could correspond to the very small well-formed crystals of calcite observed by TEM (Fig. 5B). Moreover, the reference values for the argillite vary according to the stratigraphic level: being around 1717.5 wt.\% in CD318 and at deeper levels (CD854 and CD994), and $14-15$ wt.\% in CD700. Such variations reveal a degree of stratigraphic heterogeneity in the sedimentary Toarcian sequence that has been discussed previously (Michel, 1999). 



Fig. 5. TEM images of mineral phases observed in the black rim of CD318 sample. (A) Newly formed illite crystals (arrow) observed in the outer part of the black rim overgrowing on illite/smectite mixed-layers; (B) occurrence of well-formed crystals of authigenic calcite; (C) C-S-H, very fine fibrillar, at the argillite/cement paste contact; (D) $\mathrm{C}-(\mathrm{A})-\mathrm{S}-\mathrm{H}$ with crumpled foil-like habit around carbonate particle.

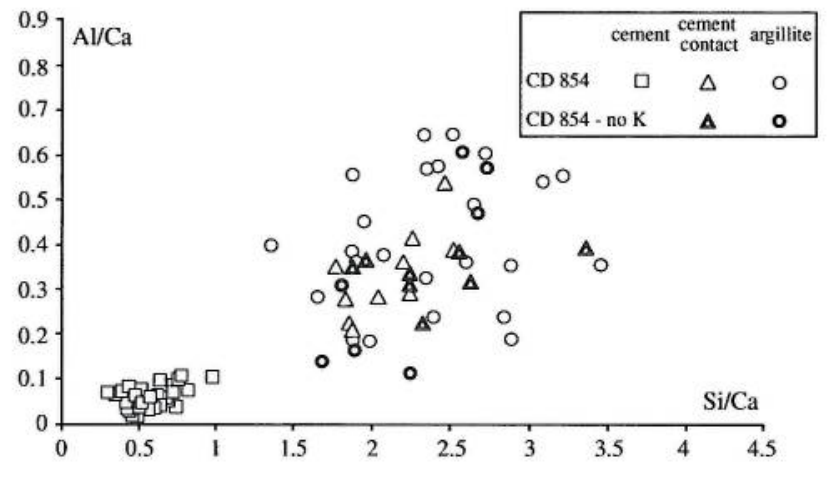

Fig. 6. $\mathrm{Si} / \mathrm{Ca}$ versus $\mathrm{Al} / \mathrm{Ca}$ atom ratios for $\mathrm{C}-\mathrm{S}-\mathrm{H}$ of the $\mathrm{CD} 854$ sample.

\subsection{Chemical and isotopic evolution}

\subsubsection{In the cement paste}

The $\mathrm{Sr}$ isotope composition of the soluble phase from the alteration front of the cement paste, and mainly in the $0-8 \mathrm{~mm}$ interval close to the argillite interface, appears to be significantly different from that observed in the unaltered zone (Fig. $3 \mathrm{~F}$ ). The ${ }^{87} \mathrm{Sr} /{ }^{86} \mathrm{Sr}$ ratio is lower in the zone exhibiting the input of less radiogenic Sr. Such a trend can be explained by the formation of the carbonates and/or C-S-H new phases from a fluid poor in radiogenic Sr, possibly in equilibrium with the argillite soluble phase. This hypothesis is discussed further below in the light of the modelling.

\subsubsection{In the argillite}

From an isotopic point of view, the carbonates from the black rim of the argillite are clearly distinguishable from reference values, since they have low $\delta^{13} \mathrm{C}(-0.92 \%$ to $-2.81 \%)$ and $\delta^{18} \mathrm{O}$ signatures (24.5-25\%o) (Fig. 7). These values define an intermediate domain between the marine carbonates of the Toarcian argillite $\left(-0.5 \% \circ \quad \delta^{13} \mathrm{C} ; \quad 25.6 \% \circ \quad \delta^{18} \mathrm{O}\right)$ and the cementitious material $\left(-17.1 \%\right.$ and $+18.5 \%$ for $\delta^{13} \mathrm{C}$ and $\delta^{18} \mathrm{O}$, respectively). Such trends are in agreement with MCM measurements and, as for the DM-borehole (Techer et al., 2012), can be explained by the neoformation of some new $\mathrm{CaCO}_{3}$ phases that precipitated from a cementitious fluid. The cementitious fluid signature in the black rim is also highlighted by considering the $\mathrm{Sr}$ isotopic measurements obtained from the argillite soluble phase. In the reference Toarcian zone, in the deep levels, homogeneous and $l o w{ }^{87} \mathrm{Sr} /{ }^{86} \mathrm{Sr}$ ratios are recorded regardless of the distance to the black rim (Fig. 7), with a mean value of $0.70799\left( \pm 5 \times 10^{-6}\right)$ corresponding to seawater composition at the time of deposition of the argillite (Koepnick et al., 1990), which is in agreement with previous data (Michel, 1999). In the black rim, significant higher ${ }^{87} \mathrm{Sr} /{ }^{86} \mathrm{Sr}$ ratios are measured for the soluble phase with values ranging from 0.708030 and $0.708300\left( \pm 5 \times 10^{-6}\right)$. These values are clearly intermediate between those determined in the reference Toarcian sediment and in the cement paste, which yields a mean value of 0.70847 ( \pm $5 \times 10^{-6}$ ). However, along a profile crosscutting the black rim, the increase in $\mathrm{Sr}$ isotopic ratio appears to be neither constant nor continuous. The variation of the isotopic ratios defines bellshaped profiles, which reflect a zonation with certain levels proving to be more radiogenic than others. At the same time, the $\mathrm{Sr}$ content of the soluble phase appears to increase in the black rim from the unaltered zone to the cement interface (Fig. 8). These trends can be interpreted as resulting from the transport of $\mathrm{Sr}$ (and by analogy $\mathrm{Ca}$ ) from the cement paste towards the sedimentary material. The mixing between the two types of $\mathrm{Sr}$ in the black rim ('sedimentary' Sr with a marine signature, and 'cementitious' $\mathrm{Sr}$ with a more radiogenic composition) can be visualized in a ${ }^{87} \mathrm{Sr} /{ }^{86} \mathrm{Sr}$ versus (1/Sr) diagram (Fig. 8) (Faure, 1986; Techer et al., 2012). The mean $\mathrm{Sr}$ contents and ${ }^{87} \mathrm{Sr} /{ }^{86} \mathrm{Sr}$ ratios characterising the Toarcian pristine soluble phase extracted by leaching are around $10.7 \mu \mathrm{mol} \mathrm{L}^{-1}$ and 0.70799 , respectively. In the cement paste, the soluble phase appears to be more Sr enriched and to have more radiogenic $\mathrm{Sr}$, with concentrations ranging from 17 
D. Bartier et al./.
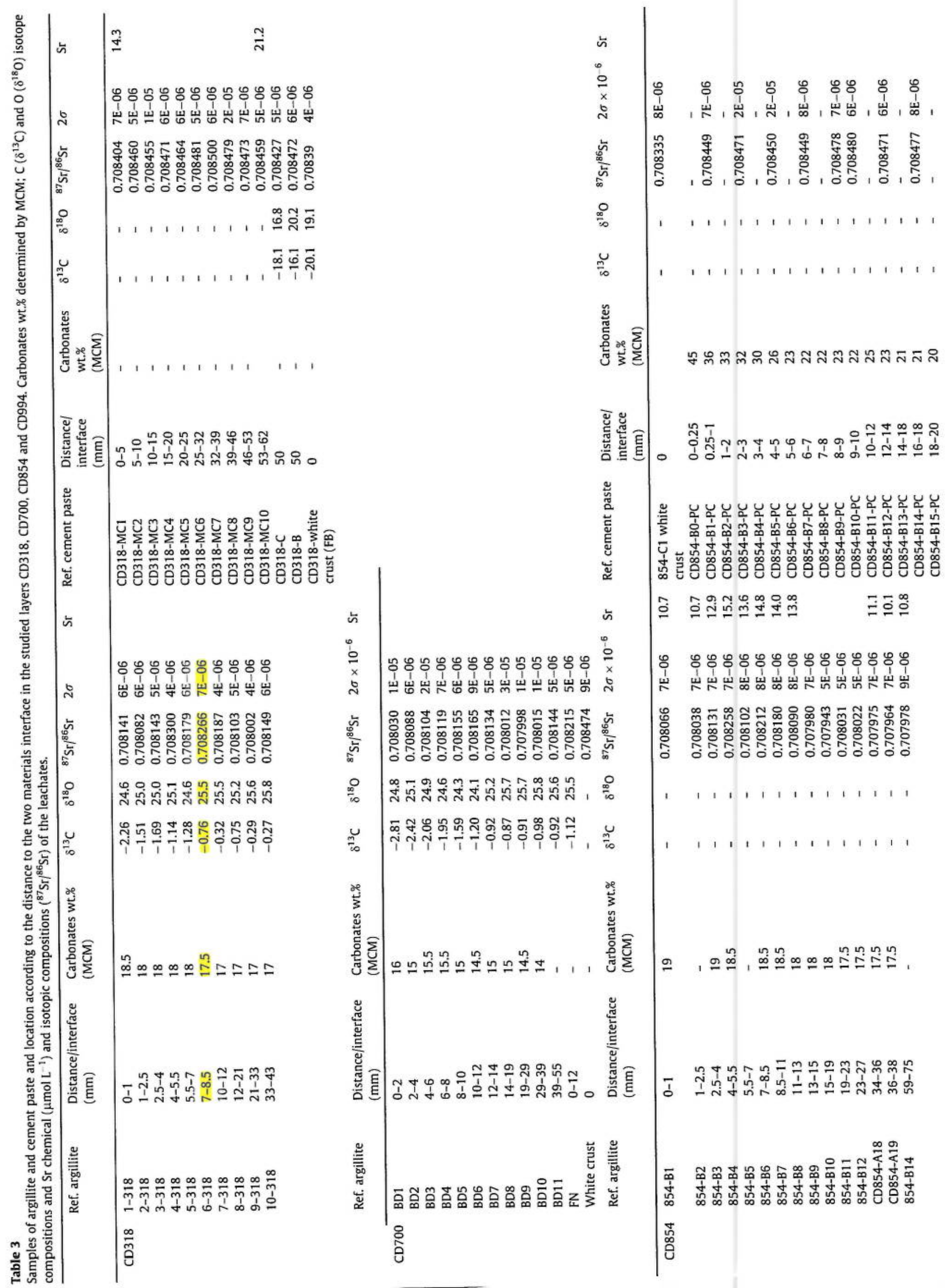
and $21 \mu \mathrm{mol} \mathrm{L} \mathrm{L}^{-1}$ and a mean ${ }^{87} \mathrm{Sr} /{ }^{86} \mathrm{Sr}$ ratio of 0.70847 . All values measured in the black rim of the argillite, which is intermediate between these two domains, can be fitted by a mean mixing line supporting the hypothesis of transport of cementitious fluids into the argillite (Fig. 8). The bell-shaped profiles observed previously could correspond to a variation of the proportion of newly-formed phases over the thickness of the altered zone. Thus, the $\mathrm{Sr}$ isotopic and elemental signatures of the CD black rim are consistent with the neoformation of a large amount of cementitious soluble phases as observed previously. These phases correspond to carbonates and $\mathrm{C}-\mathrm{S}-\mathrm{H}$ type phases, in agreement with SEM and TEM observations.

\section{Numerical modelling and discussion}

The numerical simulation of 18-a interaction between the CEM II cement paste and the Toarcian argillite in the CD-borehole gives a good reproduction of the mineralogical changes observed in the clayey material as well as in the cement paste (Fig. 9). In the cement paste, the modelling results indicate a decalcification with portlandite dissolution, $\mathrm{C}-\mathrm{S}-\mathrm{H}$ decalcification, and carbonation with calcite formation. In the argillite, HYTEC points to montmorillonite dissolution and illite precipitation linked to the alkaline plume diffusion, as well as $\mathrm{C}-\mathrm{S}-\mathrm{H}$ formation due to decalcification of the cementitious material and a small amount of calcite dissolution.

\subsection{Cement paste evolution in a saturated-out-EDZ configuration}

Portlandite dissolution can be considered as a marker of the cementitious material perturbation. Fig. 10 compares the portlandite profiles obtained by XRD and by the modelling. The perturbation front for this phase shows a slightly different thickness when considering modelling or in situ measurements. Its thickness is under-estimated by the calculation, i.e. $3 \mathrm{~mm}$ as against $3-4 \mathrm{~mm}$ observed. This difference could be explained by Archie's law, which possibly over-estimates the effect of interface clogging due to calcite formation. Nevertheless, the result is considered as very acceptable for a long-duration experiment. Moreover, there is a perfect correlation between the XRD quantification of portlandite content and the value calculated by the hydration model: around $6 \mathrm{mmol} / \mathrm{L} \mathrm{of}$ portlandite is expected in the unaltered zone. An interesting result is obtained concerning the carbonation process. Both in the HYTEC simulation and in the post-mortem observations, $\mathrm{CaCO}_{3}$ formation (mainly calcite in association with relatively large amounts of vaterite) is indicated at the outermost surface of the cement paste. Vaterite formation is rare in the clay/concrete interaction, and is mainly observed during batch-precipitation of highly supersaturated solutions at room temperature (Kabasci et al., 1996; Spanos and Koutsoukos, 1998). De Windt et al. (2008) also reported vaterite as being carbonate associated with calcite and aragonite in the crusty carbonates of the concrete. Geochemical measurements obtained here do not favour the precipitation of these phases from cement paste alteration as assumed by De Windt et al. (2008), but are in better agreement with neoformation linked to the argillite perturbation. In fact, $\mathrm{Sr}$ isotope data show a change of the carbonate signature in the zone characterized by precipitation of calcite and vaterite, at the interface with the argillite and over a depth of $6 \mathrm{~mm}$. This change corresponds to a decrease of the ${ }^{87} \mathrm{Sr} /{ }^{86} \mathrm{Sr}$ ratio in comparison to the unaltered zone (Fig. 3F). The data imply the introduction of a less radiogenic $\mathrm{Sr}$ component (along with $\mathrm{Ca}$ ) in the cement paste carbonate network. This $\mathrm{Sr}$ could be derived from the carbonate fraction of the argillite, characterized by a low ${ }^{87} \mathrm{Sr} /{ }^{86} \mathrm{Sr}$ signature (mean ratio of 0.70799 ). The proportions of "sedimentary" $\mathrm{Sr}$ and "cementitious" Sr components can be determined by a mixing model coupling the 


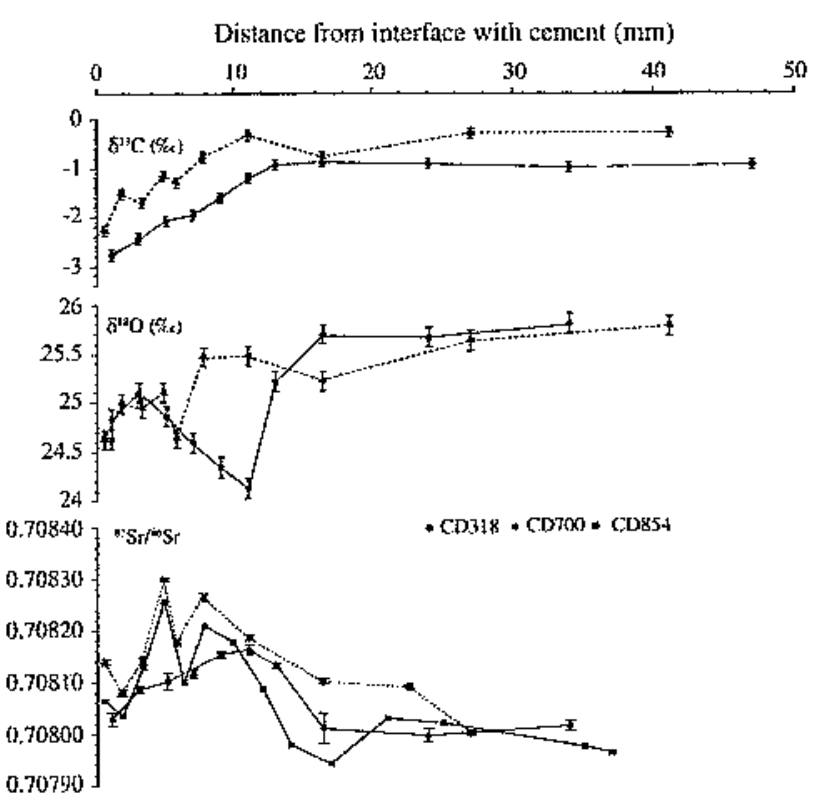

Fig- 7. Evolution of the isolopic compositions of $C, 0$ and Sr from sections CD318. CD700 and $\mathrm{CD} 854$ at varying distances from the cement paste interface.

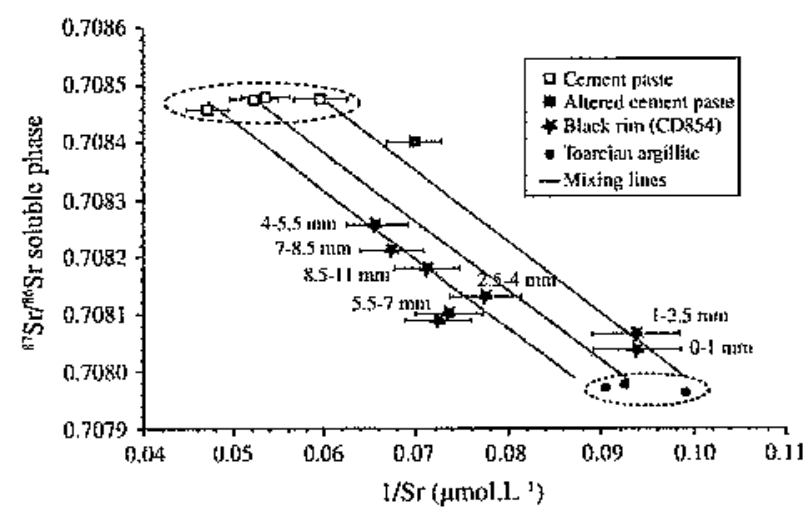

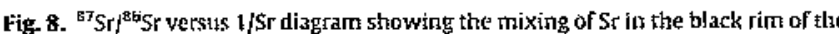
argillite and in the altered zone of the cerment paste between a 'sectimentaty' and a 'cenmentitious' reservoir. The theoretical mixing line is calculated using equations from Faute (1986).



Fig. 9. Mincralogical changes simulated with HYTEC after 18 a orinteraction at the argillitelCEM II centent paste interface.

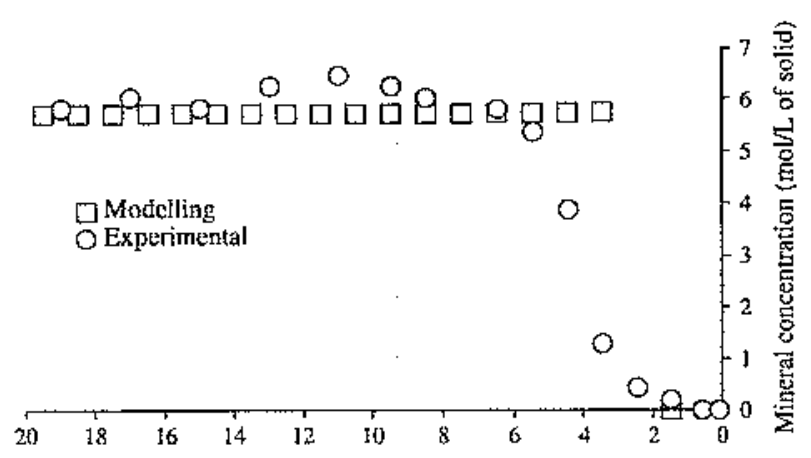

Fig. 10. Comparison of experimental and modelled portlandite profiles th the CEM Ii cement paste of the CD boreliole.

clemental concentration and the isoropic composition (Faure, 1986; Techer et al, 2012) (Fig. 8). The values measured in the altered rim of the cement paste $\left(14.2 \mu \mathrm{mol}^{\mathrm{L}}{ }^{1}\right.$ and 0.708404$)$ аге intermediate between those defined by the solsble phase of the Toarcian argillite and the cement paste, in agreement with a binary mixing model between cementitious and marine $\mathrm{S}$ r as discussed above. This mixing phenomenon reflects the transport of $\mathrm{Sr}$ and Ca from the argillite into the cement paste by diftusion. Intuitively, it would be expected that the Ca would be transported mainly from the cement paste into the argillite and not the reverse. The Ca concentration in the Portland base cementitious material, which is about $20 \mathrm{mmol} / \mathrm{L}$ at $25^{\circ} \mathrm{C}$ is controlled by the portlandite phase, in the presence of an alkaline component (mainly $\mathrm{KoH}$ ), the $\mathrm{Ca}$ concentration in the pore solution is reduced. It is possible to obtain very high concentrations of $\mathrm{KOH}(400-500$ mmol/L) (hyperalkaline solution). In this case, the Ca concentration is strongly re duced (to uround $f$ or $2 \mathrm{mmol} / \mathrm{L}$ ). As a result, the Ca concentration in the pore solution of the cementitious material rends to be lower than in the argillite pore solution. This equilibritum could explain the presence of sedimentary $\mathrm{Ca}$ in the carbonates sampled from the cement paste (diffusion of $\mathrm{HCO}_{3}^{-}$and $\mathrm{Ca}^{2+}$ from the argillite). It is interesting to examine these changes by modelling and monitoring the very short-term chemical behaviour of the $\mathrm{Ca}$ in the pore solution. Fig. 11 shows the $\mathrm{Ca}$ flux calculated as a function of time. Clearly, in the short-term (up to 0.5 days), the Ca fron the argillite pore solution diftuses into the cement paste according to a diffusion gradient. Very rapidly, the flux is definitively reversed, mainly due to the leaching of alkali from the cement paste, which then feads to increasing Ca concentration in its pote solution (Fig. 12). As a result, short and long term processes that are superposed in the engineered analogue can be discussed here.

Finally, the modelling also provides information on changes in the composition and nature of the $\mathrm{C}-\mathrm{S}-\mathrm{H}$ phases: these minerals bave a relative abundance of about $40 \%$ in the unaltered zone and between $50 \%$ and $60 \%$ in the altered zone. This increase is in

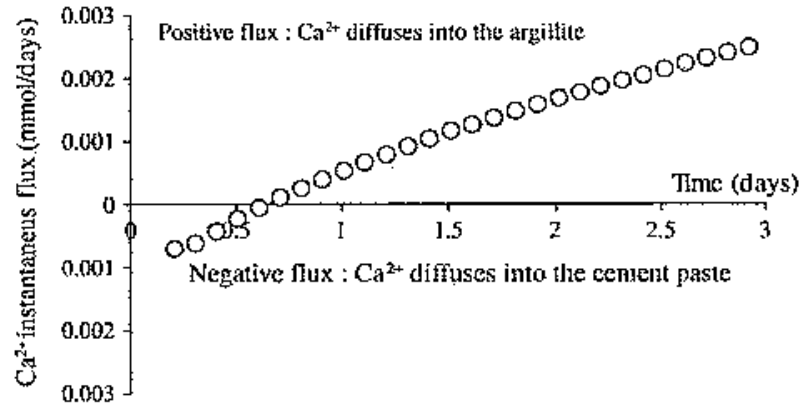

Fig 11, HYTEC modelling of Ga flux at the clayfement' paste interface. 


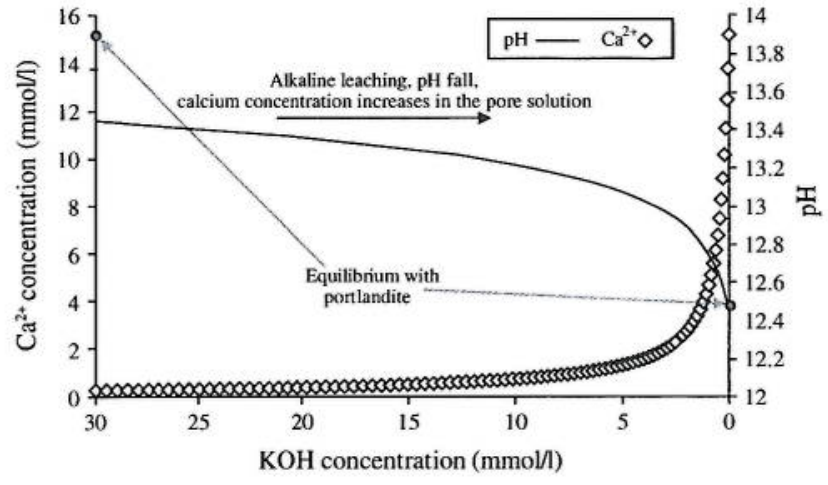

Fig. 12. CHESS modelling of the $\mathrm{KOH} / \mathrm{Ca}$ /portlandite equilibrium at $25^{\circ} \mathrm{C}$ in a cement paste - influence of $\mathrm{KOH}$ leaching on Ca concentration.

agreement with the observed in situ variation in specific area (Fig. 3D). The decrease in $\mathrm{CaO} / \mathrm{SiO}_{2}$ ratio (Fig. 3B) in the cement paste can also be related to the $\mathrm{C}-\mathrm{S}-\mathrm{H}$, which displays a decreasing $\mathrm{CaO} / \mathrm{SiO}_{2}$ ratio between the unaltered zone and the contact with the argillite. This ratio decrease is characterized by an extension of the tetrahedral Si chains (increased content of $\mathrm{Q}^{2}$ sites) linked to the formation of $\mathrm{C}-\mathrm{S}-\mathrm{H}$ with more extensive large sheets, which, therefore, have a higher specific area. The source of $\mathrm{Si}$ for this $\mathrm{C}-\mathrm{S}-$ $\mathrm{H}$ probably comes from the argillite, with portlandite dissolution supplying the $\mathrm{Ca}$ for the formation of this phase. Moreover, HYTEC modelling (Fig. 9) displays for instance a decrease of $\mathrm{C}-\mathrm{S}-\mathrm{H} 1.65$ near the surface and an increase of $\mathrm{C}-\mathrm{S}-\mathrm{H} 0.8$.

\subsection{Argillite modifications in fluid saturated configuration outside the $E D Z$}

HYTEC simulation shows illite precipitation over the entire thickness of the altered zone (Fig. 9) and TEM analyses of the MLM particles in the black rim could also argue for an illitization process (Figs. 4 and 5). Moreover, TEM observations at the outer edge of the black rim display authigenic illite laths overgrowing mixed-layer illite/smectite. This overgrowth process is enhanced by the very low specific surface area measured in this zone. The transformation of smectite into illite is widely described in the literature, but it is a complex mechanism affected by several factors favouring or inhibiting the reaction as for instance temperature (Hower et al., 1976), pressure (Eberl and Hower, 1977) and the chemistry of the $2 / 1$ layers (in Andra, 2005). The influence of solution chemistry on the degree of illitization has also been investigated in experimental studies (Eberl, 1978; Roberson and Lahann, 1981; Huang et al., 1993; Mosser-Ruck et al., 2001). All these studies indicate that the availability of $\mathrm{K}$ is a key factor in illitization and this latter parameter can be considered as having a crucial influence in this study. Indeed, for the URL Tournemire, the illitization with more than $70 \%$ illite in the illite/smectite ratio could likely be observed because $\mathrm{K}$ is present in large amounts $(>100 \mathrm{mmol} / \mathrm{L})$ in the pore solution of the cement paste in the form of $\mathrm{KOH}$. HYTEC simulation also exhibits $\mathrm{C}-\mathrm{S}-\mathrm{H}$ formation due to decalcification of the cementitious material. C-S-H formation observed by TEM in the black rim of the $\mathrm{CD}$-borehole can be readily related to the $\mathrm{C}-\mathrm{S}-\mathrm{H}$ neoformation causing the clogging of the porosity in the DM-borehole black rim (Gaboreau et al., 2011). The argillite of the black rim can be clearly distinguished from the reference argillite, since it contains carbonates with low $\delta^{13} \mathrm{C}$ and $\delta^{18} \mathrm{O}$ values (Fig. 7). These values define an intermediate field between the marine $\mathrm{CaCO}_{3}$ and cementitious materials, highlighting an exchange process (mainly related to isotopic diffusion in a fluid phase) in the black rim between the diagenetic and authigenic carbonates. The "cementitious" nature of the latter can be demonstrated by analogy with the DM engineered analogue (Techer et al., 2012). These data reflect an elemental flux in the argillaceous sediment coming from the cement paste, which is mostly enriched in $\mathrm{Ca}$. This flux can also be estimated by considering the $\mathrm{Sr}$ isotopic composition of the soluble phase extracted from the argillite far from and close to the cement paste. The argillite just beyond the black rim, yields isotopic compositions typical of the 'marine' reference. These data help to define the exact extent of the imprint of cementitious fluids strictly limited to the black rim. This result is interesting since it is completely different from that described in the DM-engineered analogue, where zones of alteration were much larger (up to a few centimetres) (Techer et al., 2012). Geochemical disturbances are observed in the DM-analogue both in the black rim and also far beyond this zone. In the same way, when looking at sample CD318, which was collected from an environment similar to that in the DM-borehole, we find evidence for a geochemical $\mathrm{Sr}$ disturbance beyond the black rim. It appears that structural discontinuities in the EDZ have a major influence on the propagation of cementitious fluids, and lead to a greater imprint of this fluid than can be observed when propagation is only controlled by the matrix. Outside the EDZ, fluid percolation within the clayey matrix is strictly limited to a $10-12-\mathrm{mm}$ thick zone expressed as a black rim.

\section{Conclusions}

This study presents a characterization of cementitious and argillaceous materials from engineered analogues at the Tournemire experimental platform (IRSN, Aveyron, France). This analogue, called the $\mathrm{CD}$-borehole, provides a singular contact that has not been studied previously. Most samples are located in a mechanically undisturbed zone in constant saturation under in situ conditions during an exceptionally long period for an experiment (18 a). Post-mortem characterization of materials combined with modelling of reactive transport using the HYTEC code proves to be a very good approach to outline the nature and scale of disturbances that may occur in claystones interacting with cement paste, as expected under the conditions of deep radioactive waste storage. In such a context (saturated conditions outside the EDZ), the modification of the hardened cement paste over $18 \mathrm{a}$ is mainly controlled by carbonation and portlandite dissolution, as well as successive ettringite precipitation and dissolution, and, finally, by $\mathrm{C}-\mathrm{S}-\mathrm{H}$ decalcification. In the argillite, the imprint of the hardened cement paste is limited to a black rim, where it corresponds to a slight illitization of the illite/smectite mixed layer minerals as well as $\mathrm{C}-(\mathrm{A})-\mathrm{S}-\mathrm{H}$ and carbonate precipitation. This study clearly demonstrates that (i) both cement and argillite exhibit structural and mineralogical alterations, (ii) argillite modifications are controlled by changes taking place in the cement paste and (iii) conversely, part of the cement paste modifications are also controlled by changes in the argillite, with the result that (iiii) the cement paste/argillite contact is a dynamic boundary zone where both sides need to be taken into account. This study allows obtaining a main reference point for the near-field migration of perturbations over a period of 18 a across the clay/cementitious material interface.

\section{Acknowledgements}

The authors would like to thank the CNRS and IRSN for funding this Project in the framework of the GNR TRASSE (Research Action Number 2008-2B). Thanks are due to Mikaël Lefèvre and Krzysztof Suchorski for their help during the stable isotopes analytical ses- 
sion. The authors also thank Michael Carpenter for his professional English language review.

\section{References}

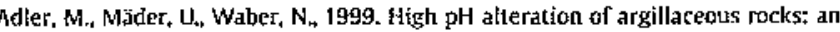
experimental study. Stl weiz Mineral. Fettogt. Mitt. 79, 445-454.

Mlexander, W.:2, Dayal, R.. Eagkeson. K., Eikenberg, J., Hamilton, E, 1992. A ratural aralogue of high $\mathrm{pH}$ cernent pore waters from the Maparin area ef nothen Jordan. 1l: results of ptedictive geochemical calculations. J. Gcochem. Explor. 46. $133-146$.

Andra, 2005. Dossier 2005, rêférentiel des matẹ́riaux d'un stockage de dêchets haule aclivité ef a vie longue, rome $b$, marériaux fapport $\mathrm{H}^{\mathrm{C}}$ CRPASCM040015Tt.doc.

Baker, A,j., Hateman, K., Fyslop, F.K., Ilett, D., Linklater, CM $_{+}$Milodowski, A.E., Noy, D. .. Rothelle, C.A. Tweed, C., 2002., Research on the Alkaline Disturbed Zone restilting from Eement Water-Rork Reactions around a Cementitjous Repository in a Silicate-rich Host Rock. Nirex Report NfO54, UK wirex Ltd. Harmell, UK,

Bauct. A., Berger. G. 1998 . Kaolinite and smectite dissolution rate in high molar KOH solutions at 35 and $80{ }^{\circ} \mathrm{C}$. Appl. Geocham. 13, 905-916.

Bensenouci, fi, 2010. Apport des traceurs naturels a la compröhension des trantferts au soir des formations argileuses tompactées. Thàse de JUniversité Paris-Strd 11.

Berner, L.R. 1992. Evolution of pore water chernistry during degradation of coment in a radicactive Wasle repository environment, Waste Manage. 12, 201-219.

Boisson, J.Y., Bertiand, L, Heitz. J.F., Moreay-Le Golvan. Y., 2001. to silu and laboratory investigations of fiud llow through an argillaceous formation at different scales of space and time, Tournemire tunncl, southern France. Hydrogeol. ]. 9, $108-123$.

Bouchet, $A_{\text {. }}$ Casagnabère, $A_{4}$, parneix, J.C. 2004. Batch experintinents: results on WXo0. In: Michas, N, (tdd) Ecoclay II: Effect of Cement on Clay Barrier Petformance Filase II, Final Rcport, (ANDRA). European Contract FIKW-CT$2000-0028$.

Cltarpentier, D., Mosser-kuck, k, Cathelineau, M., Guillatume, D. 2004. Oxidation of argilfites in a tunnel (Toumemire, France): consequences on minecalogy and coystal thentisty of clays. Clay Min. 39 (2), ₹35-149.

Chen, J.... Thomas, ].J., Taylor, H.F.W., Jennings, H.M.M., 2004. Solubility and structure of calcium silicate hydrate. Cen, Conct, Res. 34, 1A99-1519.

Claret, F. Bàtuter, A., Schafer, I, Griffault, L, Lanson, B. 2002. Experitmenta! investigation of the interaction of clays with hish-pH soltaions: a case stady from the Gillovo-Oxfordias formation, Meuse-Haute Marre underground laboratory (France). Clays Clay Miner. 50, 633-646.

codina. $M_{+}$2007. Les bétons bas pH - Formulation, caractórisation et étude a long terme. Thèse de linstilut Natînal des Sciences Appliquées de Toulouse.


2006. The alkaline teaction of FEBEX bentonite: a contribution to the study of the perfondace of bentonilelconcrete engineered barrier systems. J. ther. Geol. $32,15]-174$.

Dauzères, A., Le Bescop. P.. Sardini, P. CaupirCrumes, C., 2010. thysica-chemica investigation of clayey/cement-based materiais interaction in the context of geological waste dispesat: experimental approach and results. Cem. Conct. Res. $40,1327-1340$.

Devol-Brown, J. Tinseau, E., Bartier, D. Migud, A, Stammosc, D. 2007. Interaction of Foumertire atgillite (Aveyron, France) with hyperalkaline fiuids: batch experiments performed with powdered andfor compdet materials. Phys. Chem. Earth $32,320-333$

De Windt, L. Pellegrini, D., Wan der Lee, J. 2004. Coupled moleling of cenent, claystone interactions and radionuclide migration. J. Contani. Hydrol. 6B, L65182.

De Windt. L. Marsal, F., Finseat, E., Pellegrini, D. 2008. Rejctive trangport modeling of geochemical interactions at a concrete/argillite interface, Tournemife site (France). l'hys. Chem. Earth 33, 295-305.

Eberl, $D_{.1} 1978$. The teaction of thontmoritionite to mixed-layer clay: the effect of

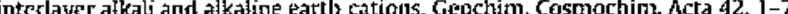

tber, 0 . Hower, 3. 1977. The hydrothermal transformation of 5odium and potassium smectite into mixed-layer clay. Clays clay Miner. 25, 215-227.

Eberl, D.D. Velde, $B_{-1}$ Mc Cormick, $T_{4}$ 1983. Synthesis of illite-smectile from smetite at Earth surface temperatures and high ply. Clay Min. 28, 49-60.

Elie, M., Techer, 1., Trotignon, L. Khoury. 1i., Salameh, E., Vandanme, D., Boulvais, P. Foltrcade, $S_{-}$2007. Cementation of kerogen-rich marts by alkaltine flutds reteased during weatherin of themally metamorphosed marly sedinyent.5. Pafr Il: organic matter evolurion, magnetic susceptibility and metals ( $\mathrm{T} ; \mathrm{Cr}$, Fe) at the Khushaym Matruk natural analogue (Central Joroisn), Appl. Geochem, 22 , $1311-1328$.

Faure, G., 1986. Principles of Isctope Geglogy, second ed. John Wiley \& Sots.

Femánclez, $R_{n}$ Cuevas, J. Maider, U., 20t0. Modeling experimental results of diffusion of alkaline solutions through a compacted bentonite bartinr. Cem. Concr, Kes, 40, 1255-1264.

Fourcade, 5. Fecher, J., Boulvais, P. Elie, M. Trotignon, L., Vandamme, D. 2007. Cementation of a clayey sediment by alkaline huids teleased by combistionprodtced cements: 1 . Isatopic $(C, O)$ and paleomagnetic study or the Khushaym Matrutr natural allalogue (Central Jordan). Appl. Geochem. 22, 1293-1310

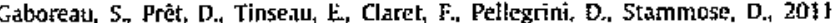
15 Years of in situ cement-riggillite interaction from Tourtemire URL: cluaraterisation of the multi-scaje spatial heterogencities of pore space evolution. Appi. Geochem, 26, 2155-2171.

Harvey, C.o., 1943. Some noles an the calculation of molecular formulae for glaticonite, Am. Mineral. 28, 541-543.

Hidalgo, A. Petit, S. Domingo, C.. Alenso, C., Mndrade, C. 2007. Microstruttural cluaraterization of leaching effects in centent piste duc to nestralization of their alkaline natere - Part I: Jortland cement pastes. Cemr. Concr. Res. 37. 6370.

Hower, ]. Fslinger, EV, Hawer, M. Persy, E.A., 1976. Mechanista of burïal metamorphism of argllaccous sediments: 1. Mineralogical and chemical evidence. Geol. Soc. Arit. Bulf. 87, 725-737.

Huang, W,L, longe, J.M., Pevear, D.R., 1993. An experimentally derived kiratic madel for smectite-to-illite conversion and its tose as a geotluermometer. Clays Clay Minet. $41,162-177$.

Kabasci, C, Nithaus, W. Weinspactr, P.M., 1996. Batch-presipitation of calcium carbonate from highly supersaturated solutions. Chem. Eng. Res. Des. 74, 76572

Kinoury. H., Salameh, E, Altdul-Jatuer, Q. 1985. Characteristics of an unusual highly alkaline water from the Magarin alcea, nerthern Jordan, I. Hydrel. 8L, 79-91.

Koepuick, R.B., Denison, R.E, Burke, W.H., Hetheriggton, E.A., Dafl, D.A., 1990. Construction of the Triassic and jerassic portion of the Phanerozoit curve of seawater ${ }^{87} \mathrm{Sr} / \mathrm{SF}$. Chem. Geol. 89, 327-349.

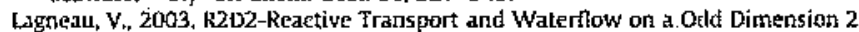
Grid, Rapport LHM/kD/03/05. Centre d'Informatique Géologitulte, Ecole des Mires de Paris, Fontainebleau.

Lothenbach, B., thätsłeì, T., Moscbner, G. Glasser, F.P. 2008. Thermodynamic modelling of the elfect of temperacture on the hydration and porosicy of Portland cemert. Cem. Concr. Res. 38, 1-18.

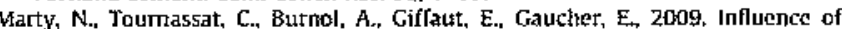
reaction kinetics and meslt refinement on the numerical modelling of concrete, thy fnteractions. J. Hydrol. 364, 58-72.

Matray. !-M., Savoye, S., Cabrera, !., 2007. Desatuliation and structure relations hips around dril'ts excavated to the wal-compacted Fourncmire's afgitlite (Aveyron. Fratice). Eng. Geol, 90, 1-16.

McCtea, I.M. 1950 . On the isnotope chemistry of carbenates and a paleotemperzture scale. J. Ghem. Pliys, 18, 849-857.

Miched, $P_{+}$1999. Caractérisation isotopique $R b / 5 r$ el $\mathrm{Pb} / \mathrm{Fb}$ des foches totales, des miner rau de remplissage de fraclure et des eatux des formations sédtmentaires jurassiques de Tournemire (Aveyron, France). Implications sur les interactions

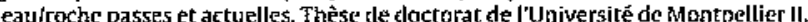

Mosser-kucts, R., Cathelineatu, M., 2004. Ekperimental tiansformation of $\mathrm{Na}$, Casmentite under basic conditions at $150^{\circ} \mathrm{C}$. Appl. Clay 5ci. 26, 259-273.

Mosser-Fuck. R., Pironon, J., Catlelineat, M.. Trouiller, $A_{\text {, }}$ 2001, Expefimental

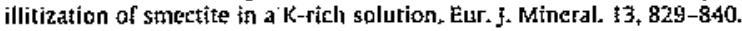

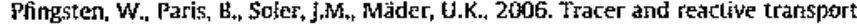
madelting of the interaction between hish-pH fluid and fractured rock: field and laborationy expariments. j. Geochem. Exploc. 90. 95-113.

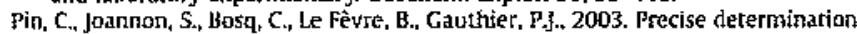
of $\mathrm{Rb}_{1} \mathrm{Sr}_{\mathrm{r}}, \mathrm{Ba}$ and $\mathrm{pb}$ in geological materials by isotope dilation and ICPfuadrupola mass spectrometry following selective separation of the analytes. I. Anal. Atom. Spectrom. I8. 135-141.

Ramirex, S.R. Cuevas, f. Vigil, R, Leguey, S. 2002. Hydrothermal alteration of * $L$ Serrata * bentonite (AImeria, Spain) by alkaline solutions. Appl. Clay Sci. 21. $257-269$.

Read, D., Glasser, F.P., Ayota, C, Gurrdiola, M.T., Sneyers, A., 2001. Mineralogical and mictestructural charges accompanying the interaction of Borm Gay with ordinary Portland cemerit. Adv. Cern. Res. 13, 175-183.

Richardson, I.G., 1999. The nature of C-S-H in hardened cements, Cem, Concr, Res. $29,1131-1 \pm 47$

Richardson, I.C., 2000. The nature of the liydratation products in laudened cenent pastes Cement Concrete Comp, 22,97-113

Richardson, I.G.- 2008. The calcium silicate lyydrates. Cem. Concr, Res. 38, 137-15.

Roberson, H.E., Lahtann, RW. 1981. Snectite to itite conversion sates: effect of solution themistry. Chays Clay Miner, 29, 129-135.

Savage, D. 2011. A review of anajoguas of akkaline ateration with regard to longterm barrier performance. Ainerał. Mag. 75, 2401-2418.

Savage, D. Noy, D. Mitharz, M. 20,12. Modetting the inceraction of bentonite with hyperatkatine fluids. Appl, Grochem. 17, 207-223.

Smeilie, j* 1998. Maqarin Natural Aralogue Study: Pitase III. SKB Technical Report Th-98-04, Swedish Nuclear fuel and Waste Management Company, Stockholm.

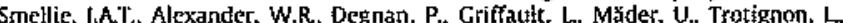
2001. The rele of the Jordan natural analogue studies it the performance assessment of cementitious repositories for radioactive wastes. In: Eidu, $R$. (Ëd.), Water-kock Interation 10. WRJ 10, vol. 2. A.A. Baikena Publishers. Leiden, The Netherlands, pls. 1391-1393.

Spanos, $N_{\text {, k Kutsoukos, P.G }}$ 1998. The trarzsformation of vaterite to calcite: effect of the conditions of the solutions in contact with the mineral phase, J. Cryst. Growth 191, 783-790.

Steelel, CI., Lichtser, P.C, 1998. Mutticomponent reactive transport in discrete Iractures If: infiltration of lyperalksiline groundwater at Maqurin, Jorctan, a natural athatogue sire. J. Hydrol. 209, 200-224

Faylor, K. Richardson, t.G., Brydson. K.Mi.O. 2007. Nature of C-S-H in 20 year old geat ordinary Patland cement and 10\% Portland cement-9os ground granulated bfast furnace slag pastes. Adv. Appl. Ceram. 106. 294-301.

Techter, I. Bartier, D., Boulwais. Pl., Tínsedu, E.. Suchorski, K. Cabrera. J, Dautzètes, A. 2012. Tracing interactions between natural arghlites and typer-atkalite lluids 
from crgincored cement paste and concrete; chemical and isotopic monitoring of a 15-years old depp-disposal analoguc. Mppl, Geochem. 27. 1384-1402.

Techer, 1., Khoury, H,N, Rassineux, F, 5atagith, E., Clauda, C, Clauer, N., Pagel, M., Lancelot. J., Griffault, I., Jacquol, E., 2006. Propagation of allaline fivids ift an: argillaceotus formation: sturdy of the Khushaym Matruk natural andogote (central Jordan). 1. Geochen. Explor 90. 53-67.

Tinseat, E., Bartier. D., Hassoutan, L. Devol-Brown, I, 5tammoșe, D, 2006. Mineralogicat characterization of the Toumemire argilite after in siru interaction with concretes, Waste Manage. 26, 789-800.

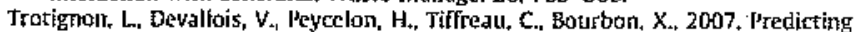
the tong lerm durabitity of concrete engineered barriers in a geological repository los radioactive waste. Phys. Chem. Eath 32, 259-274.

Trotignon, $L$. Peycelon, tt. Bourbon, $X .2006$. Campasison of performance of concrete bactiess in a claycy geologica! medium. Phys. Chem. Earth 31, 6to617.
Van der Lee, J. 1998. Thermodynatric and mathematical concepls of chess, Techuical Report No LHM/RD/98/39. Ecole des Mines de Phis. Fontaintbleau, France.

Wan der see, f., De Windt, L., Lagneau. W, Goblet, P., 2003. Module oriented nodeling of roactive transpost with HYCEC, Comput. Geosci. 29, 265-275.

Van Der Pluijm, BA., Lee, J.t.., 把acor, D.R., 1996. Anajytical problem of potassiura diffusion, Clays Glay Miner. 36. 498-504

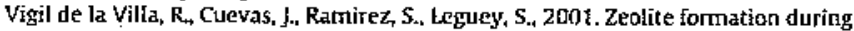

the alkaline reaction of bentonite, Eur, J. Mireral, 13, 535-644.
Yamagucti, T., Katooka, M., Sawaguctij. T.. Mukai, M., Hoshino, S., Tanaka, T., Marsal, F.. Pellegrimi, D., 2012. Development of a Heactive Transport Code MC-Cement VER2 and its Verification using 15-years in-situ Conerete/Clay tritaractions at the Tournenire URL ANDRA Sth lnt. Meeting, Montpellier, October 22-25. 2012 . 